\title{
Aristófanes y Eurípides
}

\author{
Luis GIL \\ Universidad Complutense de Madrid \\ luisgilfer@hotmail.com
}

Recibido: 29-09-2012

Aceptado: 20-12-2012

\section{RESUMEN}

Del examen (I) de las menciones nominatim a Eurípides, de los pasajes donde total o parcialmente se le cita o imita (II), y de su función en las piezas aristofánicas en que figura como personaje (III) se deduce la ambivalente postura de admiración y odio de Aristófanes frente a Eurípides. Le considera (I) un poeta бoৎóc,

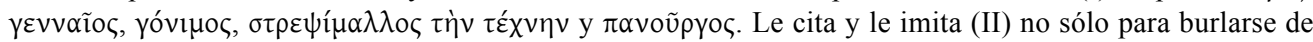

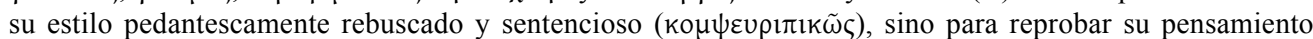
cuando lo estima dañino o moralmente peligroso. Como personaje teatral desempeña (III) la función positiva de ayudar al héroe cómico en Ach. y Thesm. En Ran. Dioniso lo pone como poeta trágico en pie de igualdad con Esquilo y sólo un motivo político lo inclina a llevárse a éste a Atenas consigo: su actitud favorable a Alcibíades. La política también explica las críticas de Ran. a ciertos aspectos del teatro euripideo como el excesivo patetismo y la 'democratización' de los personajes, que para Aristófanes implicaban la degradación de la tragedia.

Palabras clave: Aristófanes, Eurípides, comedia, tragedia, paratragedia, parodia.

\begin{abstract}
Aristophanes' ambivalent mix of admiration and hatred with respect to Euripides can be inferred from examination (I) of the nominatim references, the passages in which he is partially or totally quoted or imitated (II), and his role in plays where he features as a character (III). Aristophanes considers Euripides as a poet бoфós,

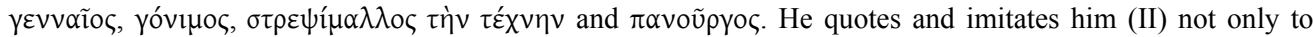

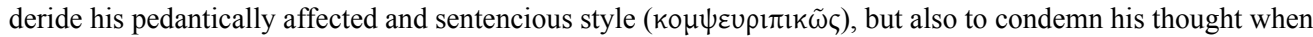
he deems it harmful or morally dangerous. As a character Euripides plays (III) the positive role of helping the comic hero in Ach. and Thesm. In Ran. Dionysus presents him as a tragic poet on an equal footing with Aeschylus and only political reasons move him to take Aeschylus along to Athens: his favourable attitude towards Alcibiades. Politics also explain the criticism in Ran. with regard to certain aspects in Euripidean drama such as the excessive pathos and the 'democratisation' of characters, which for Aristophanes entail a downgrading of tragedy.
\end{abstract}

Keywords: Aristophanes, Euripides,comedy, tragedy, paratragedy, parody.

Entre los komoidoumenoi de Aristófanes se impone reconocer que Eurípides goza de un status especial. Otros personajes contemporáneos con los que el cómico se enfrentó en su momento por razones políticas, literarias o religiosas, como Cleón y Só- 
crates, dejaron con el tiempo de llamar su atención y después de muertos merecieron su silencio. No es ése el caso de Eurípides de cuyo influjo no pudo librarse a lo largo de toda su existencia. No sólo lo sacó a escena en Los caballeros (424 a.C.) y en Las tesmoforiantes (411) estando el trágico con vida, sino en Las Ranas (405) cuando había ya fallecido. Incluso en la última de sus comedias conservadas, el Pluto (388), Aristófanes vuelve a emplear (v. 601) una frase del Télefo (fr. 713 Kannicht) de la que había hecho uso en Los caballeros (v. 813) ${ }^{1}$ treinta y seis años antes. No es mucho lo que un aserto tan simple nos puede indicar sobre la pervivencia de Eurípides en la memoria de Aristófanes, pues podría tratarse de una frase que hubiera pasado al dominio público, pero son tantas y tan concretas las alusiones al trágico en todas sus obras que no pueden explicarse más que con la ayuda de una biblioteca personal en la que figurasen los dramas euripideos, como ha sugerido Walter Kraus (1975: 454) ${ }^{2}$. Pese al énfasis puesto en la Mündlichkeit frente a la Schriflichkeit del gran siglo de la cultura ateniense, es innegable, como Platón nos lo recuerda en el Fedón, que por un módico precio eran accesibles las obras de los filósofos en el mercado ateniense. Más aún, el propio Aristófanes le hace a Dioniso confesar en Las Ranas (v. 52) que la lectura de la Andrómeda de Eurípides durante una travesía por mar le despertó tal añoranza del dramaturgo que le impulsó a irlo a buscar al Hades ${ }^{3}$.

Tan evidente era la presencia de Eurípides en la producción de Aristófanes que Cratino pudo encararse así con él: «¿Quién eres tú? preguntaría un espectador inteligente, tú, decidor de sutilezas, perseguidor de sentenciejas, eurípides-aristofanizante?» ${ }^{4}$. El cómico admitió el reproche, aunque con un pequeño matiz: «Uso, sí, la rotundidad de su boca, pero los pensamientos los hago menos vulgares que él» $\rangle^{5}$. Incluso reconoce

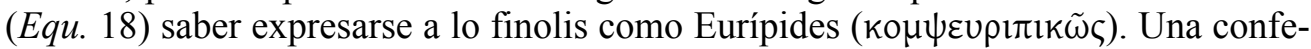
sión que plantea otro problema. Si Aristófanes se burla del estilo de Eurípides, pero lo imita, ¿cuál era en el fondo la opinión que de dicho estilo tenía? El problema se complica cuando se compara el diferente trato que dispensa al dramaturgo, a Cleón y a Sócrates cuando los pone en escena como personajes de sus obras. El Sócrates de Las Nubes es una figura tan perniciosa para la ciudad como la del Paflagonio-Cleón de Los Caballeros. Ambos son derrotados, pero la solución final en ambas piezas es muy diferente. El Paflagonio es sustituido en el favor de Demos por el Morcillero

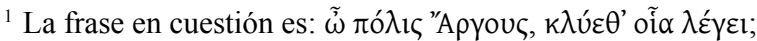

${ }^{2}$ Comparten su opinión Christine Hunziger (2000: 99-110) y Gian Franco Nieddu (2003: 55-90) en lo relativo a entender la parodia de la Helena euripidea en Las tesmoforiantes. En cambio Giuseppe Mastromarco (1994: 8-12) y (2006: 137-191) estima que el recuerdo de las representaciones trágicas por parte del público explica la comprensión de las parodias cómicas de éstas. Sin embargo, desde el punto de vista del autor cómico, el simple recuerdo no basta para justificar la reproducción literal de un amplio número de versos, a veces tomados de varias obras y hay que suponer la ayuda de textos escritos. Para una discusión del tránsito de la oralidad a la literalidad, vide G. Cerri (1969: 119-133).

${ }^{3}$ Otras referencias a libros en la comedia aristofánica se encuentran en Ranas, 1114, 1409, en el

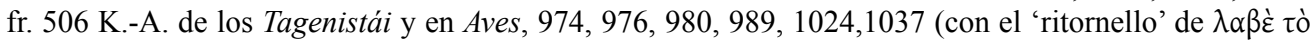
ßıß入íov), 1289.

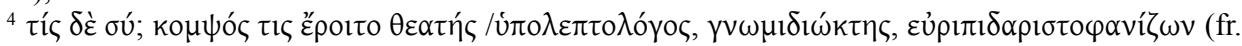
488 K.-A.).

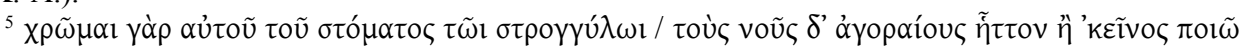
(fr. 488 K.-A.). 
transfigurado en Agorácrito. En cambio, Las nubes no terminan con un happy end, boda, banquete o komos gozoso, como suele ser lo habitual en la comedia aristofánica, sino con un final catastrófico: el incendio del Pensadero y la expulsión de Sócrates y sus discípulos ${ }^{6}$.

Muy diferente es la figura de Eurípides en Los acarnienses. Aunque ridícula, cumple la positiva función de ayudar a Diceópolis en su defensa contra los airados miembros del coro. Y lo mismo se ha de decir de su cometido en Las tesmoforiantes. Si origina el conflicto del Pariente con las mujeres, lo resuelve también satisfactoria y de-

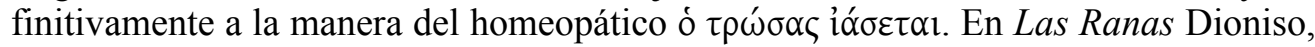
ateniéndose sólo a criterios literarios es incapaz de decidirse entre Esquilo y Eurípides, y para tomar una resolución debe acudir a consideraciones políticas. ¿Cuál era el fallo, en verdad, que le merecía a Aristófanes la tan admirada por sus contemporáneos como controvertida figura de Eurípides? Porque, como un aserto suyo hace pensar, la crítica de Eurípides se había puesto de moda entre los cómicos contemporáneos. En el prólogo de Las avispas el siervo Jantias pone sobre aviso a los espectadores de que no esperen de la obra que van a contemplar chanzas vulgares al modo de las piezas megarenses, ni a esclavos que arrojen nueces sobre el público, ni a Heracles defraudado de una cena, ni tampoco una nueva insolencia contra Eurípides (v. 61) ${ }^{7}$. Para tratar, pues, de hallar una posible respuesta a éstos y parecidos interrogantes se ha de seguir a nuestro juicio el siguiente procedimiento:

I. Examinar los asertos que ocasionalmente se introducen sobre el trágico nominatim en la totalidad de la producción aristofánica.

II. Pasar revista a todas las citas de Eurípides hechas por Aristófanes, tanto textuales, como cómicamente alteradas o construidas sobre su modelo.

III. Analizar la función de Eurípides en las piezas donde el cómico lo introdujo como dramatis persona.

Y más o menos es esto es lo que pretendo hacer en lo que sigue, pero antes conviene saber en qué consiste ese $\varepsilon u ̉ \rho \imath \imath \imath \delta \alpha \rho \tau \tau o \varphi \alpha v i ́ \zeta \varepsilon ı v$ que le imputaba Cratino a

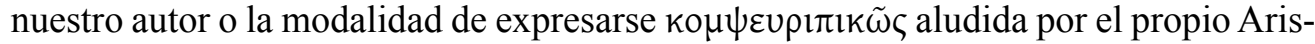
tófanes. Y esto nos obliga a referirnos a la debatida cuestión dentro de la comedia aristofánica de la llamada 'parodia' o 'paratragedia' por los filólogos de los siglos XIX y $\mathrm{XX}^{8}$, términos jamás usados por el comediógrafo, que emplea en su lugar el más

${ }^{6}$ E. C. Kopff (1977: 113-122) llega incluso a creer que los espectadores de Las nubes abandonarían el teatro pensando que a continuación se les mataría a Sócrates y a los suyos.

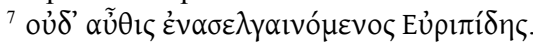

${ }^{8}$ Pueden enumerarse los trabajos de H. Täuber (1849), J. Van Leeuwen (1876), W. R. Ribbeck, (1861), Id. (1863), Id.(1864), O. Delepierre (1890), W. H. Van de Sande Bakhuyzen (1887), A. Murray, (1891), W. Passow (1897), W. E. Hoppe (1906), C. Pascal (1911), F. Guglielmino (1928), H. Steiger (1934: 161-164, 275-285, 416-432), A. C. Schlesinger (1937: 294-305), F. W. Householder, (1944: 1-9), E. Roos (1951), F. J. Lelièvre (1954: 66-81), C. Prato (1955), Anna M. Komornicka (1967: 51-74), P. Rau (1967), E. Pöhlmann (1972: 144-56), E. Degani (19833), M. ${ }^{a}$ Grazia Bonanno (1987:135-167), Elena Magnini (1997: 127-138). En lo transcurrido del presente siglo el interés por el tema no ha disminuido, como demuestran el trabajo de Francesca Delnieri (2000: 107-114), la obra colectiva de E. Medda, M. ${ }^{\mathrm{a}}$ 
sencillo de $\mu \iota \mu \varepsilon \tilde{\imath} \sigma \theta \alpha l^{9}$. En efecto, como dice G. Mastromarco (2008:177), «uno degli elementi più caratteristici della poetica aristofanica $(\mathrm{e}$, in generale della commedia del quinto secolo) è la parodia tragica (ovvero paratragodia), una forma letteraria che consiste nella ripresa e nel contestuale stravolgimento a fini comici di un modelo tragico di un testo comico». Nos hallamos, pues, ante un caso particular de $\mu$ ínضoıs en la que Platón y Aristóteles pusieron tanto el origen de las artes como el del goce estético. Las creaciones de las artes plásticas imitan la realidad de la naturaleza y el goce estético que producen reside en el reconocimiento de su modelo por la mente de quienes las contemplan. De forma parecida el comediógrafo remedaría las obras trágicas y en el reconocimiento de éstas por los espectadores residiría el goce cómico que se manifestaría en la risa. Dentro del acervo bibliográfico consagrado al tema desde el siglo XIX a nuestros días y de la confusión terminológica ${ }^{10}$ a que ha dado lugar, me interesa hacer unas precisiones. Por 'paratragedia' entiendo la transposición sistemática a términos cómicos del argumento o de las escenas de una tragedia determinada, por 'parodia', la creación de un texto nuevo a imitación del estilo trágico, en nuestro caso del estilo peculiar de Eurípides.

Que nos hallamos ante una verdadera paratragedia ${ }^{11}$ únicamente lo podemos con-

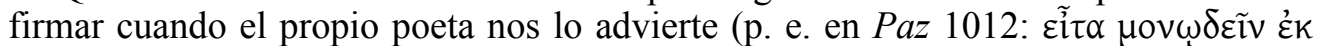

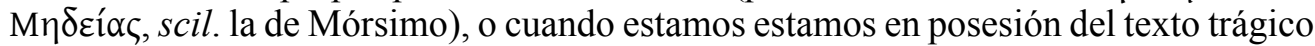
parodiado, o al menos de amplios fragmentos suyos. Este es el caso de la Helena ${ }^{12}$ y de la Andrómed $a^{13}$ euripideas, ambas piezas de una trilogía ${ }^{14}$ representada el año anterior a Las tesmoforiantes. Cuando no ocurre así, dependemos de las observaciones de los escolios o de la investigación filológica para determinar si nos hallamos ante una 'paratragedia' o una mera 'parodia' del estilo trágico. Gracias a los escolios conocemos

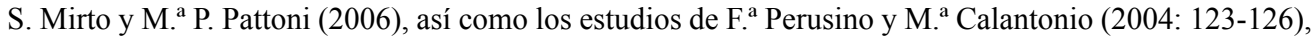
M. ${ }^{\text {a }}$ P. Funaioli (2007: 98-107), G. Mastromarco (2008: 177-188), M. Pellegrino (2009: 202-216) y M. di Marco (2009: 119-146).

${ }^{9}$ Cf. Vesp. 1019, Plut. 291-2 y especialmente Thesm. 850, donde el Pariente expresa su deseo de

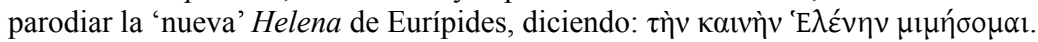

${ }^{10}$ Valgan de muestra unos ejemplos. Para A.T. Murray 'paratragedia' es la imitación del estilo y la manera de escribir de un autor sin referencia especial a una obra o a un pasaje determinado. H. Steiger subordina a lo 'burlesco' tanto la 'parodia' (tema trivial y frívolo presentado en un estilo elevado), como lo 'travesti' (tema noble hecho a propósito trivial). Para P. Pucci, 'parodia' es la alusión cómica con la intención principal y tal vez única de burlarse de un estilo particular, la paratragedia es la imitación de un estilo trágico cuando la intención de burlarse no es evidente. Este autor emplea el término $\tau \rho u \gamma \omega \delta i ́ \alpha$ para designar un pastiche alusivo a la tragedia desde el punto de vista estructural como una monodia o una esticomicia que usurpa el estilo trágico elevado para expresar sentimientos banales o bajos. Guglielmino considera tres aspectos de la tragedia: la literaria, la mitológica y la filosófica. Anna M. Komornicka la literaria, la filosófica, la retórica, la de la música, danza y puesta en escena, la de los dioses, mitos, cultos y ritos religiosos. En una palabra, todo puede parodiarse.

${ }^{11}$ Prefiero en vez del extendido 'paratragodia' castellanizar el término, ya que a diferencia del alemán 'Tragödie', 'Komödie', nosotros decimos 'tragedia', 'comedia'.

${ }^{12}$ Le ha dedicado un estudio particular P. Rau (1975: 339-54).

${ }^{13}$ Han sido estudiada por W. Mitdoerffer (1954: 59-93), V. Coulon (1957:186-198), P. Pucci, (1961: 369-384), P. Rau, op.cit., G. Mastromarco (2008: 177-88).

${ }^{14}$ Cf. schol. 1012 Regtuit a Thesm. 
los pasajes de Los acarnienses y de Las tesmoforiantes que se basan en el Télefo, sabemos que el Trigeo de La paz cabalgando en su hipo-escarabajo parodia el Belerofontes, y que también en Las tesmoforiantes hay una cómica alusión al Palamades, todas ellas piezas de Eurípides. Cuando los escolios faltan nos es imposible determinar la pieza a la que corresponde un determinado pasaje de indudable sabor 'trágico', si dicha pieza no se conserva. Al contrario, en otras ocasiones podemos tener la seguridad de hallarnos ante una genuina creación paródica, como es el caso del anagnorismós de la anguila por Diceópolis (Ach. 881-94), aunque los escolios nos informen de que el v. 883 está tomado de la "O $\pi \lambda \omega v$ кpíorৎ de Esquilo y los vv. 881-94 de la Medea. Y el mismo convencimiento podemos tener con la monodia trenódica de Glice en Ran.1331-1364. Pero siempre quedará un resquicio para la duda, pues la parodia no sólo afecta al lenguaje, los metros, los gestos, la danza y escenografía, sino a todas las estructuras del género trágico: los relatos de mensajero, las esticomicias, y los reconocimientos.

Aristófanes se burla de la lengua de Eurípides, arcaizante y rebuscada a veces,

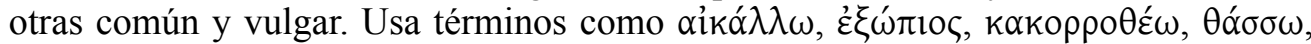

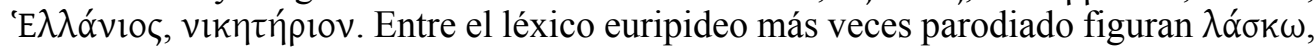

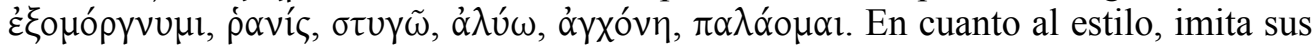

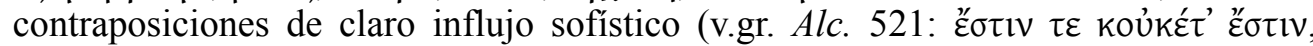

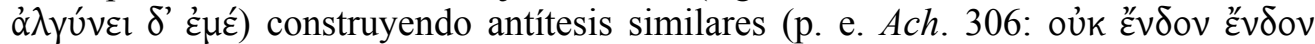

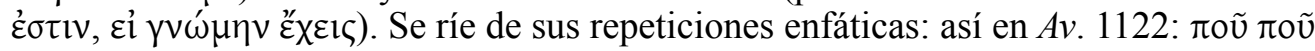

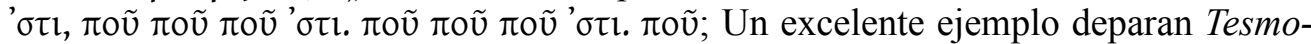

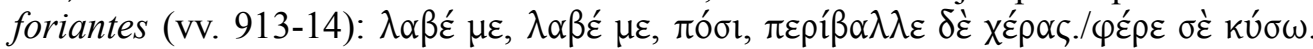

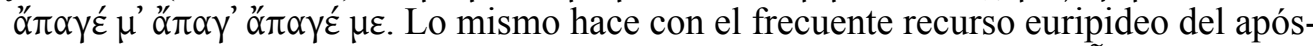

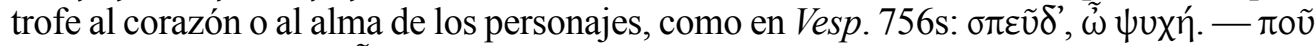

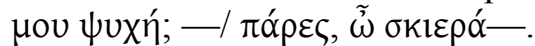

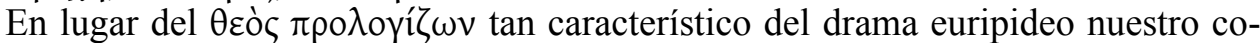
mediógrafo recurre a un siervo o a un par de ellos para informar al espectador de lo

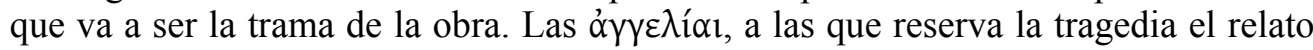
de escenas espeluznantes, las utiliza, dado el carácter jovial de la comedia, para poner al espectador en conocimiento de hechos que caen fuera de la representación, p. e. el relato del accidente de Lámaco en Ach. 1174ss., el de lo acontecido en la asamblea en Asambleistas o en el Asklepieion durante la incubatio de Pluto en la pieza del mismo nombre. Se ha observado la ausencia del aumento en los relatos de los mensajeros de la

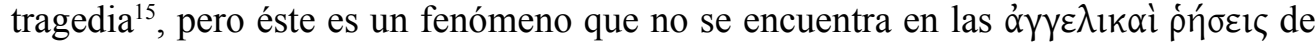
Aristófanes. Ejemplos de esticomicias son las de Trigeo y su hija (Pax 124-49), Trigeo y Hermes (ibid. 185-200), Lisístrata y el semicoro de las mujeres (Lys. 706-16). El cómico deforma el texto original mediante la distorsión de uno de sus elementos o la interpolación de otros nuevos (el ejemplo típico es el de $\lambda \eta \kappa u ́ \theta ı v ~ \alpha ́ \pi \omega ́ \lambda \varepsilon \sigma \sigma v)^{16}$. P. Pucci (1961:

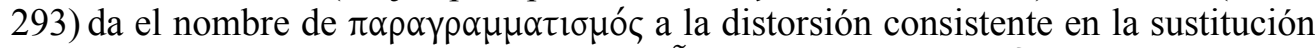

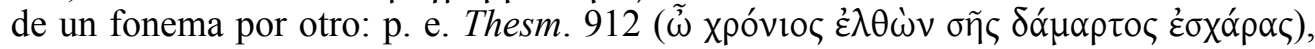

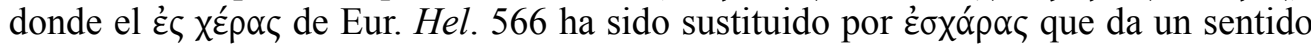
obsceno al encuentro de los esposos. Para pasar del tono trágico al cómico Aristófanes

\footnotetext{
${ }^{15}$ Cf. L. Bergson (1953).

${ }^{16}$ Son éstos los términos que emplean E. W. Handley - J. Rea (1957: 23-24).
} 


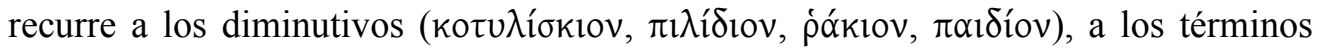

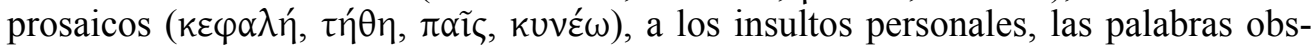
cenas, la interpolación de nombres propios (Mópuxos en Ach. 887), la ruptura de la ilusión escénica y al aprosdóketon.

En cuanto a los metros paródicos de Eurípides, P. Pucci hace notar que los 3ia son puros, carecen de resoluciones y suelen tener una cesura pentemímeres fuerte que deja el segundo hemistiquio en la forma de un lecitio (2tro $\left.{ }^{\wedge}\right)$, p. e. Ach. 460:

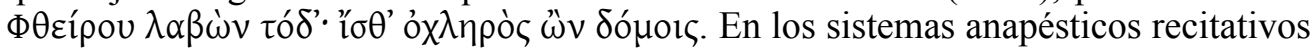
los anapestos y los espondeos son los metros predominantes ${ }^{17}$. Rara vez aparece el proceleusmático y la inversión dactílica. En los sistemas mélicos hay mayor libertad y el paremíaco deja de ser clausular y alterna con los 2 an. Aristófanes se sirve de la música y la estructura trenódica de los sistemas anapésticos trágicos para burlarse del aspecto excesivamente patético del teatro euripideo. El 4tro^ que aparece en el golpe de mano de Diceópolis en Acarnienses según Pucci no proviene del Télefo de Eurípides, sino del de Esquilo, ya que la pieza euripidea (representada el 438 a. C.) pertenece a una época en la que este autor no solía emplear dicho metro ${ }^{18}$. El docmio expresa en los kommoi y en los threnoi sentimientos de dolor, angustia y dudas, pero también alegría. En Aristófanes todas las estrofas docmíacas son paratrágicas o paródicas. En Tesmoforiantes 101 ss. los dáctilos y jónicos ${ }^{19}$ parodian la música de Agatón con gran libertad en la anaclasis, en las reducciones, contracciones y síncopas. El canto jubiloso de Estrepsíades en Nubes (vv. 1154-1170) cuando se entera de que su hijo ha aprendido al fin el argumento que le permitirá no pagar sus deudas emplea yambos, anapestos y docmios, unidos en gran variedad al estilo de Eurípides.

Como se ha podido ver, no es pequeño el acervo de estudios consagrados a la parodia de la tragedia euripidea en las comedias de Aristófanes. No obstante, no logran en su conjunto resolver el gran problema de fondo. ¿Parodiaba Aristófanes por puro divertimento a la manera en que los cómicos actuales remedan las actuaciones de los cantantes de moda o los gestos y los discursos de los políticos? ¿Pretendía condenar con el ridículo los modos de expresión y las ideas que las tragedias de Eurípides difundían? Para tratar de responder a estas preguntas seguiré la pauta que me había marcado.

I. Acometamos, pues, nuestra primera tarea. Estrepsíades cuenta en Las Nubes cómo pidió a su hijo en un banquete que recitara algún pasaje de Esquilo, a lo que Fidípides se negó alegando: «A Esquilo sí que le pongo yo en primer lugar entre los poetas, lleno como está de ruido, de incoherencia, de rimbombancia y de escarpados términos» (vv. 1366-7) ${ }^{20}$. Condescendiendo con los nuevos gustos de la juventud, el viejo le sugiere que elija alguna de esas composiciones 'tan sabias' ${ }^{21}$ de los nuevos

${ }^{17}$ Vide R. Pretagostini (1976: 183-212).

${ }^{18}$ Según W. Krieg (1936: 42 ss.) el $4 \mathrm{an}^{\wedge}$ no aparece en las obras del trágico anteriores al Heracles furioso (datado entre el $421 \mathrm{y}$ el 415 )

${ }^{19}$ Para este ritmo, cf. Bernhard Zimmermann (1987: 124-132)

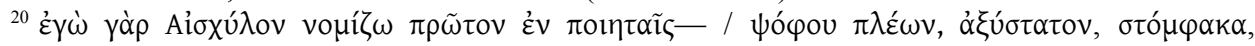
крпниотоко́v.

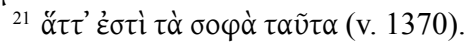


poetas. El mozo recita entonces el pasaje más escabroso del Éolo de Eurípides que narraba la violación de Cánace por su hermano Macareo, lo que provoca el escándalo paterno y el consiguiente altercado familiar. Como final de fiesta Fidípides golpea a su padre y justifica su acción con una interrogación retórica: «¿Y no lo merecías por no alabar a poeta tan excelente ( $\sigma 0 \varphi \omega ́ \tau \tau \alpha \tau o v)$ como Eurípides?»(vv. 1377-8)22. Merece la pena insistir en el adjetivo sophós que se aplica tanto al poeta como a sus composiciones, un término polivalente ('habil, 'entendido', 'capaz', 'excelente en su arte', etc.), pero que muy bien podría traducirse por 'sabio'. A este respecto hay que señalar que con dicho adjetivo se califican también las 'supuestas' obras de Eurípides en un fragmento correspondiente a Nubes II (392 K.-A.). Alguien señalando con el dedo a Sócrates informaría a su interlocutor: «Ése es el que le compone a Eurípides esas tragedias tan célebres y sabias» ${ }^{23}$. Y lo mismo afirmarían otros cómicos ${ }^{24}$.

Las dos menciones de Eurípides en Las Avispas no son en exceso ilustrativas. En el verso 61 el autor advierte a los espectadores que no esperen encontrar en la pieza

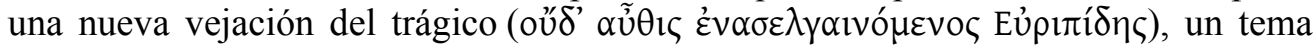
cómico, al parecer, tan socorrido como las burdas gracias megarenses, la glotonería de Heracles o los ataques a Cleón. En los vv. 1412-1414 uno de los personajes euripideos sirve para caracterizar a Querefonte. Dice Bdelicleón, en su función de juez casero: «Y también me parece natural, Querefonte, que seas tú el testigo de una mujer macilenta que parece Ino agarrada a los pies de ... Eurípides $»^{25}$. En la tragedia del mismo nombre, Ino suplicaría a su marido Melicertes, preso de un ataque de locura, que no la matase con su hijo. La aparición del nombre del autor del drama en lugar del personaje mítico es uno más de los aprosdóketa de Aristófanes.

Mayor información sobre el contenido y el estilo de las tragedias de Eurípides se encuentra en dos pasajes de $L a$ Paz. Montado ya en su enorme escarabajo, Trigeo se dispone a remontar su vuelo al cielo. Su hija le advierte. « $i$ Ojo! No tropieces y te caigas de ahí. Luego, cuando te quedes cojo, le darás a Eurípides el argumento y te convertirás en tragedia» (vv. 146-48) ${ }^{26}$. Se critica la afición del trágico a presentar personajes tullidos en sus obras, como Télefo y Filoctetes, ambos con heridas purulentas e incurables, o Belerofontes, cojo después de haberse caído de su caballo alado Pégaso. Trigeo evoca ante Hermes el aroma de la Paz a «fruta, a hospitalidad, a fiestas de Dioniso, a sones de flauta, a cantos de Sófocles, a tordos, a versitos de Eurípides» (vv. 530-32). Y Hermes le interrumpe: «Llorarás el estarla calumniando, porque no le gusta un poeta de discursejos judiciales» (vv. 532-34). Los rhematia dikaniká son las frases cortas, antitéticas, con el mismo o parecido número de sílabas (isa, párisa) y con efectos fónicos (parecheseis, homoiotéleuta), puestas de moda por los sofistas ${ }^{27}$. Y un buen

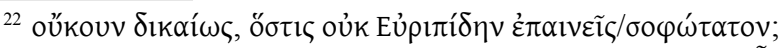

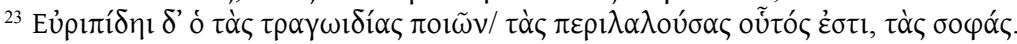

${ }^{24}$ Sobre las relaciones entre Eurípides y Sócrates, cf. Diógenes Laercio II 18, Sátiro, Vita Euripidis, col. IV, Aulo Gelio XV 20,4, Eliano, Varia historia II 13, Cicerón, Tusculanae disputationes IV 63.

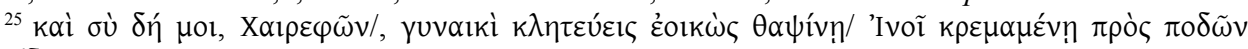
Eủpırí́ou.

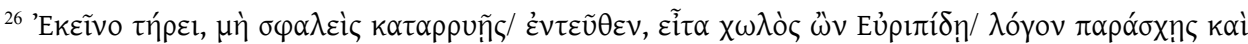

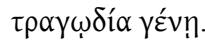

${ }^{27}$ Sobre el influjo de la retórica en Aristófanes, vide C. T. Murphy (1938: 63-113). 
ejemplo de este tipo de lexis ofrece el exordio de Praxágora (Eccl.171-188) que tiene un cierto parecido con el de algunos oradores áticos.

El coro de viejos de Lisístrata, poniendo en un plano de igualdad a los dioses y al poeta, dice que las mujeres son «aborrecidas por Eurípides y todos los dioses» (v. 283) ${ }^{28}$, aludiendo a la supuesta misoginia del trágico ${ }^{29}$, un tema de sobra conocido por los espectadores y que no aporta ninguna novedad a nuestro intento. Tampoco el fr. 596 K.-A. procedente de una fabula incerta que nos informa de un chismorreo de la época. Eurípides compondría sus obras ayudado por Cefisofonte, un esclavo suyo que tendría además comercio carnal con su mujer. Mayor interés, desde el punto de vista de la crítica literaria tiene el fr. $682 \mathrm{~K}$.-A. de otra fabula incerta por su rotunda

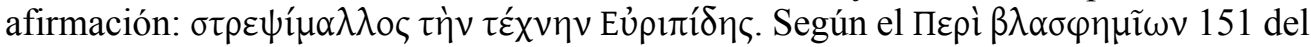

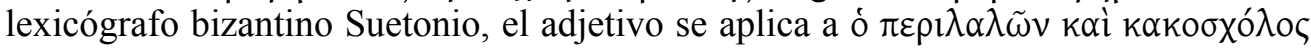
$\varphi \rho \alpha ́ \zeta \omega v$, y el origen de la denominación vendría según Eustacio, In Odysseam, p. 1638,17

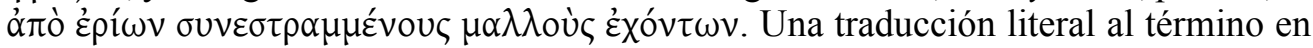
castellano podría ser 'de enredador de vedijas'.

Son Las tesmoforiantes y Las ranas las comedias que deparan mayor información sobre el arte y la ideología de Eurípides, según el juicio claro está de Aristófanes. En la primera de dichas comedias (v. 450-1) se le acusa claramente de ateísmo. Critila una vendedora de flores se queja de no vender ni la mitad que antes desde que Eurípides

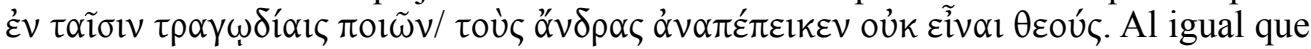
el Sócrates de Las nubes, Eurípides parece rendir culto a elementos de la naturaleza

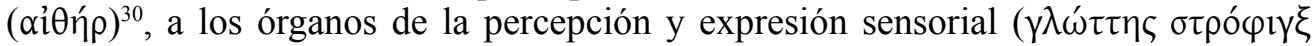

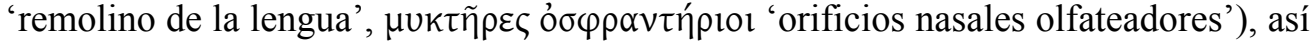

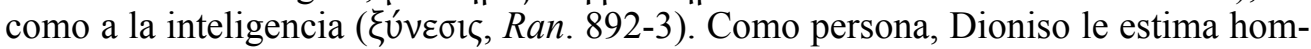
bre astuto y de muchos recursos ( $\pi \alpha v o \tilde{v} p \gamma o \zeta$, Ran. 80), lo que coincide con el concepto que tenía de sí mismo el tragediógrafo, según lo presenta Aristófanes, cuando le dice a su Pariente al abandonarlo en un momento de grave peligro: "Quédate aquí tranquilo, pues nunca mientras esté con vida te traicionaré, si mis múltiples ardides ( $\alpha i$ uvpíal $\mu \eta \chi \alpha v \alpha i ́)$ no me fallan» (Thesm. 925-7). Como poeta la divinidad tutelar

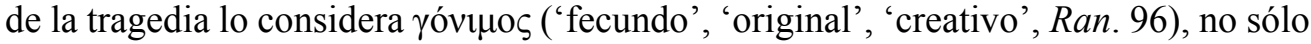

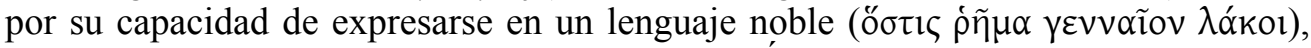
con expresiones poéticas tan arriesgadas como 'Éter dormitorio de Zeus' o 'pie del tiempo' (Ran. 100) y no menos arriesgadas sentencias cual la de «la mente no quiere jurar sobre las víctimas del sacrificio, pero la lengua perjura con independencia de la mente» (Ran. 101-102). En realidad Eurípides no calificó al aïńp de $\delta \omega \mu \alpha u ́ \tau 1 o v$ ('dormitorio'), sino de ǒ́knols ('residencia') de Zeus (fr. 487 Kannicht de Melanipa la sabia), por la cual le hace Aristófanes jurar en Thesm. 272 2 . En cambio, la metáfora para indicar el transcurso del tiempo se encuentra tal cual en el fr. $42 \mathrm{Ka}$. del Alejandro y en Bacch. 889. No ocurre lo mismo con lo que se presenta como reproducción

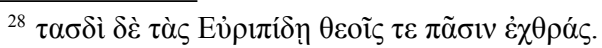

${ }^{29}$ Sobre ese particular, vide Rosella Saetta Cottone (2005: 131-156).

${ }^{30}$ En Thesm. 13-19 Eurípides le hace al éter ser la causa de la diákrisis ('separación') de las cosas en el caos original.

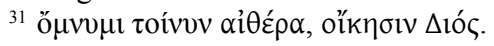


textual de un aserto euripideo. En realidad se trata de una paráfrasis de Hipólito 612. A la advertencia de la nodriza (v. 611) «Hijo, no deshonres tus juramentos», el joven responde «Mi lengua juró, mi mente no» ${ }^{32}$.

Si quisiéramos resumir los resultados de esta primera aproximación a nuestro tema con unas cuantas key words, como ahora se estila, diríamos que para Aristófanes era

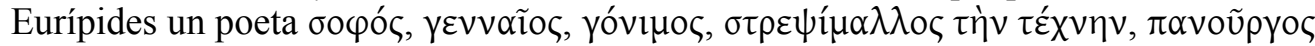
a fuer de ser fertil en $\mu \eta \chi \alpha v \alpha i ́$, pero que por eso mismo tendía a presentar a los protagonistas de sus dramas como figuras antiheroicas de mendigos y tullidos, y pecaba

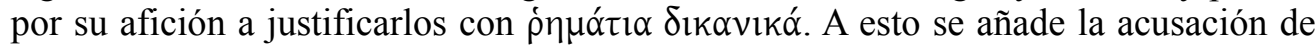
ateísmo y de inmoralidad en el tratamiento de heroínas poco recomendables para las buenas costumbres de la sociedad, aspecto éste último que se debate especialmente en Las ranas y sobre el que más adelante volveremos.

II. Llegamos al momento de abordar el punto segundo que nos habíamos propuesto, para lo cual haremos primero un censo de los materiales disponibles. Las tragedias de Eurípides de donde Aristófanes extrae sus citas, tanto textuales, como deformadas, parodiadas o imitadas son por orden alfabético las siguientes: Alcestis

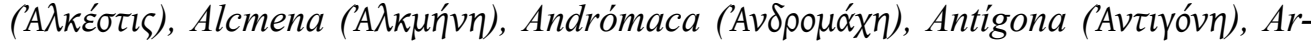

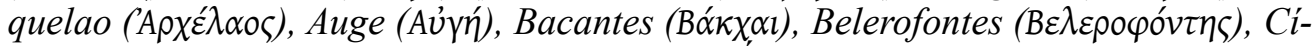

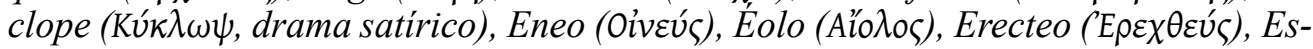

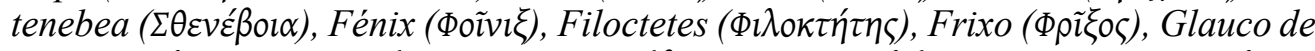

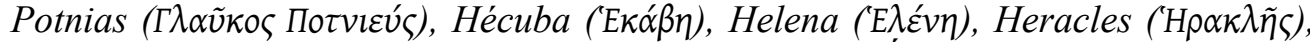

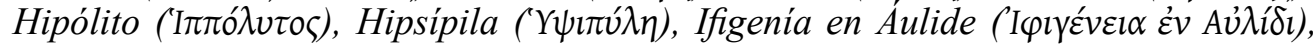

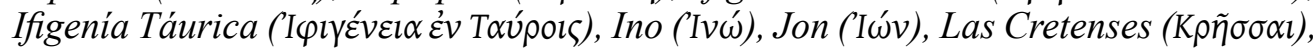

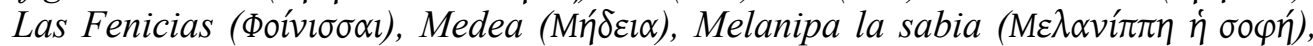

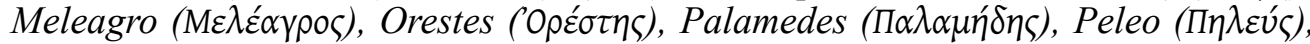

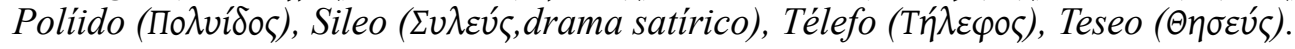

Las citas extraidas de este considerable acervo de 37 tragedias se reparten en las comedias de Aristófanes de la siguiente manera:

Acarnienses (Leneas 425 a. C.):

Alcestis (v. 367), Eneo (420), Fénix (421), Filoctetes (424), Belerofontes (426), Las cretenses $^{33}$ (433), Ino (434), Télefo (vv. 8, 446, 540-56, 576-7, 659-64, 1186-8), Hipólito (1437).

Caballeros (Leneas 424 a. C.):

Hipólito (v. 16), Belerofontes (1248-9), Télefo (813).

Nubes (Dionisias 423 a. C.):

Hécuba (173), Éolo (1371-2) Alcestis (1413-4).

Avispas ( Leneas 422 a. C.):

Estenebea (111-12), Teseo (312-14), Alcestis (750-3), Hipólito (750-3), Belerofontes (757), Las cretenses (762-3), Ino (1412-14).

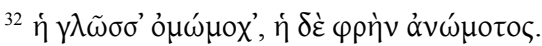

${ }^{33}$ En el verso 433 se mencionan los harapos de Tiestes, personaje que intervenía en Las cretenses de Eurípides. 
$\operatorname{Paz}$ (Dionisias 421 a. C.):

Télefo (528), Belerofontes (76, 154-6, 79-81, 721-2, 756), Sileo (drama satírico, 741). Lisístrata (Leneas 411 a. C.):

Andrómaca (155-6, 263-5, 962-66), Ifigenía taúrica (447-8), Télefo (706), Ifigenía en Áulide (884), Hipólito (1018), Melanipa la sabia (1124).

Tesmoforiantes (Dionisias 411 a. C.):

Éolo (177-8), Melanipa la sabia (272), Hipólito (275-6, 715-6), Estenebea (403-4), Fénix (413), Hécuba (499-501), Télefo (418-9, 517-9, 694-5), Palamedes (76971), Helena (855-910), Andrómaca (1009-1132).

Ranas (Leneas 405 a. C.):

Eneo (72), Alcmena (92-3, 536), Andrómeda (105), Melanipa la sabia (100, 1082, 1244), Bacantes (100), Hipólito (101-2, 105, 931, 1044, 1079, 1471), Filoctetes (282), Orestes $(304,478)$, Heracles $(562,840)$, Éolo $(850,863,1081,1475)$, Las cretenses $(850,1356-7)$, Télefo $(855,864)$, Peleo $(863)$, Meleagro $(864,12-$ 41, 1402), Belerofontes (1044), Auge (1080), Antígona (1181,1391), Arquelao (1206-8), Hipsipila (64, 1212-13, 1309-12, 1320-3), Estenebea (1217-19), Frixo (1225-6), Ifigenía táurica (1232-3), Télefo (1271), Helena (1317-19), Medea (1382), Políido (1477), Erecteo (1477).

Asambleístas ( 392 a. C.):

Orestes (404).

Pluto (388 a. C.):

fr. 690 (49-50), Medea (114), Jon (197), Cíclope (drama satírico, 290), Las fenicias (343), Hécuba (490), Télefo (601).

El influjo en Aristófanes de Eurípides como fuente de inspiración se pone aún más de manifiesto si se compara su presencia en la producción del cómico con la de los

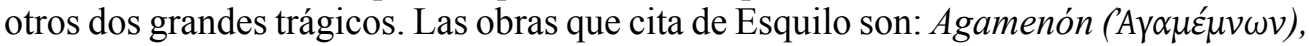

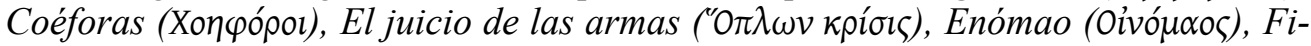

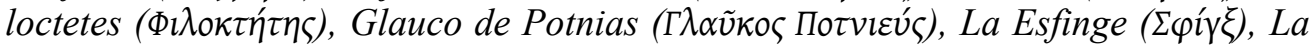

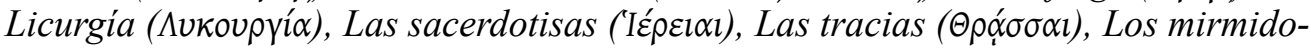

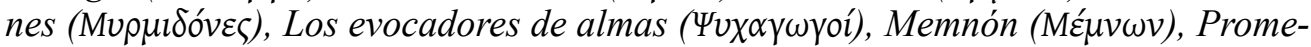

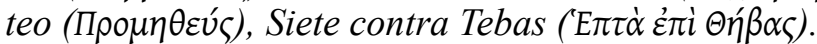

Las comedias en que los dramas esquileos se citan son: Nubes, Coéforas (vv. 8089), Níobe (1246-8), Enómao (1237-9), Lisístrata, Siete contra Tebas (42ss), Tesmoforiantes, Licurgía (134-5), Prometeo (528), Ranas, Mirmidones (992, 1264-5), Coéforas (1226-28), Evocadores de almas (1266-7), Las sacerdotisas (1273-4), Agamenón (1276, 1285-6, 1289), La esfinge (1287), Memnón (1291-2), Las tracias (1295), Filoctetes (1383), Niobe (1392), Glauco de Potnias (1403), Asambleístas, Mirmidones (390-1).

Mucho menor es la aparición de Sófocles en la producción aristofánica. Las obras

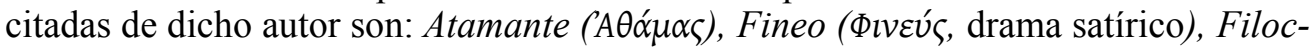

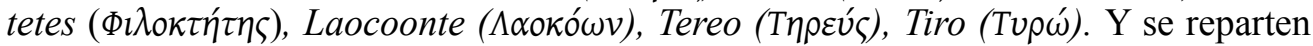
así en las comedias: Nubes, Atamante (255-7), Aves, Tereo (100-1), Tiro (275), Lisístrata, Tiro (139), Ranas, Laocoonte (664-5), Asambleístas, Filoctetes (562-3), Pluto, Filoctetes (477), Fineo, (635-6). 
La simple ojeada a los esquemas anteriores permite reconocer que el interés de Aristófanes por Eurípides fue en aumento conforme con los años la fama del trágico iba creciendo. Y esto obedece tanto a la lógica interna de la comedia, que en la parodia de la tragedia tenía una inagotable fuente de inspiración, como a los gustos personales de Aristófanes que no podía ser ajeno a las modas de su época, por mucho que aparentara serlo para congraciarse con sus espectadores entrados en años. Un pasaje de los Daitales (fr. 233 K.-A.), donde un personaje pregunta a otro el significado de algunas

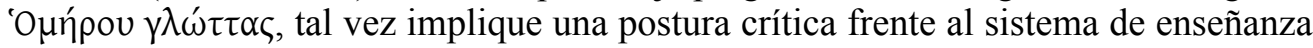
contemporáneo que obligaba a aprender las primeras letras con textos en buena parte incomprensibles para los alumnos. Pero hay más. Aristófanes se complace en reírse de sus paisanos empleando en sus obras términos a sabiendas de que no los entenderían. Así en el antepirrema de la parábasis de $L a$ paz, refiriéndose a esos gallardos taxíarcos que se pavonean con sus mantos de color escarlata, dice que en la batalla son los primeros en huir «agitando los penachos como un hipogallo amarillento» (1177-8:

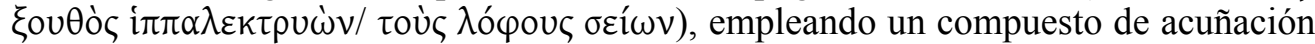
esquilea. En esa misma pieza, de acuerdo con este modelo, Trigeo crea el neologimo

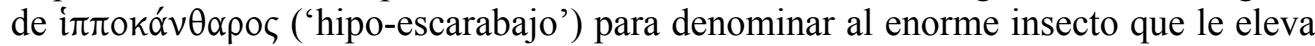
al cielo (v. 181). La paz corresponde al año 421 a. C. En Las aves (414 a. C.) vuelve a emplear el término con su correspondiente adjetivo para calificar esta vez (antepirrema de la parábasis, v. 800) a Dí́trefes, que en el mundo de las aves, a pesar de sólo tener 'alas' (= asas) de garrafa, fue elegido primero «taxiarco, luego filarco, de suerte que de la nada vive ahora a lo grande y es un cacareante hipogallo» ${ }^{34}$. Hay que esperar hasta el 404 para que Aristófanes revele su secreto. En los versos 931-2 de Las ranas el mismísimo Dioniso confiesa que muchas veces le ha quitado el sueño el intento de

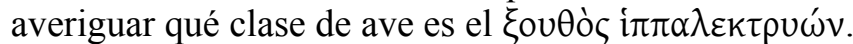

Hecho este inciso, retomamos el hilo de la exposición para ocuparnos de cómo emplea Aristófanes su material euripideo. La forma más sencilla es el préstamo de un hemistiquio para construir un verso. Así, por ejemplo, en Ach. 8, cuyo final ắııv yò 'E $\lambda \lambda \alpha ́ \delta 1$, según nos informan los escolios está tomado del Télefo (fr.720 Kannicht). K. J. Dover (1970: 14) señala con razón que en este caso y otros parecidos no se percibe intención paródica ${ }^{35}$ alguna. Se trata, como ocurre también en las lenguas modernas, de una expresión literaria que se ha generalizado en el lenguaje común. En Ranas

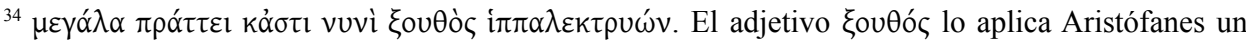

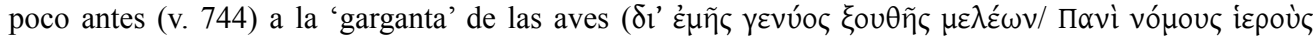
ỏv $\alpha \varphi \alpha i ́ v \omega)$. en el sentido de 'sonoro', de suerte que aquí referido al 'hipogallo' no puede significar otra cosa que 'cacareante'.

${ }^{35}$ La parodia obedece tanto al deseo de ridiculizar el estilo y el pensamiento de un escritor, como al de producir un efecto cómico por la incongruencia entre lo que se dice y el modo de decirlo, elevado para lo banal o viceversa, chabacano para lo elevado. Para la parodia es fundamental la monografía de Peter Rau (1967). Sigue siendo útil el estudio de Anna M. Komornicka (1967: 51-74), aunque peca de prurito taxonómico. A las clasificaciones enumeradas en la nota 9 , se añaden las que establece en la parodia literaria atendiendo al contenido y la forma: 1. género literario (lengua, estilo, composición 'manera'), 2. autor y su creación, 3. obra literaria concreta (poema, pieza teatral), 4. personaje de una obra literaria (Télefo, Helena), 5. escenas particulares, 6. partes de un drama (prólogo, monodia, estásimo etc.), 7. un verso o varios versos, 8 . expresión, epíteto, figura de estilo, 8 . vocablos particulares, 9 . metro. 
1471 Dioniso opta a la postre por otorgar la primacía poética a Esquilo citando, ante la

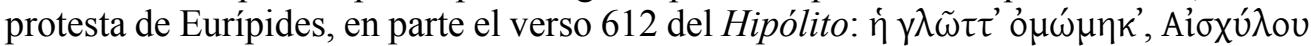
$\delta$ ' $\alpha i \rho \eta ́ \sigma o \mu \alpha l^{36}$. Y ante la nueva protesta de Eurípides (v. 1471), replica «¿Qué es ver-

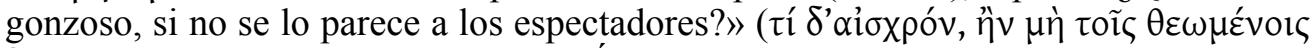
$\delta$ бoñ ; v. 1475). Se trata del verso del Éolo (fr. 19) con el que Macareo se justificaba de haber violado a su hermana Cánace, alegando: «¿Qué es vergonzoso, si no se lo parece a quienes lo hacen?», de acuerdo con la moral situacional del kaıpó ৎ de la sofística y con el relativismo antropológico del homo-mensura protagórico, Aristófanes sustituye «quienes lo hacen» $\delta \rho \omega \mu \varepsilon ́ v o l \varsigma$ por «quienes lo contemplan» $(\theta \varepsilon \omega \mu \varepsilon ́ v o l \varsigma=$ los espectadores).

Un abuso paródico de hemistiquios euripideos se encuentra en Ranas 1208, 1213, 1219, 1226, 1233, 1244 donde Esquilo critica la construcción de los prólogos de Eurípides, con ejemplos tal vez del Arquelao (fr. 228 Kannicht), de la Hipsípila (fr. 752 Ka.), la Estenebea (fr. 61, fr. 5 Ka.), el Frixo, la Ifigenía táurica (vv. 1-2), el Meleagro (fr. $516 \mathrm{Ka}$.) y Melanipa la sabia (fr. 481,1 Ka.), completando el comienzo del verso con la muletilla de $\lambda \eta \kappa u ́ \theta ı v ~ \alpha ̉ \pi \omega ́ \lambda \varepsilon \sigma \varepsilon v$. Mencionaremos sólo unos pocos casos:

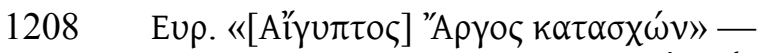
Aıх. $\quad \lambda \eta \kappa u ́ \theta 1 o v ~ \alpha ̉ \pi \omega \lambda \varepsilon \sigma \varepsilon v$.

1225-6 Evp.

AloX.

1232-3 Evp.

Alox.

1240-1 Evp.

Alox.

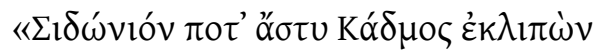

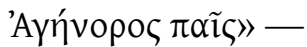

$\lambda \eta \kappa u ́ \theta 1 o v a ̉ \pi \omega ́ \lambda \varepsilon \sigma \varepsilon v$.

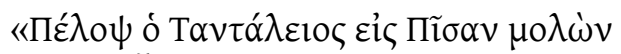

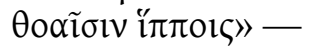

$\lambda \eta \kappa u ́ \theta 1 o v ~ \alpha ̉ \pi \omega ́ \lambda \varepsilon \sigma \varepsilon v$.

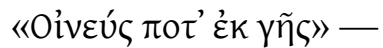

$\lambda \eta \kappa u ́ \theta t o v a ̉ \pi \omega ́ \lambda \varepsilon \varepsilon \sigma \varepsilon v$.

Esquilo afirma (v. 1203) que destruirá los prólogos de las tragedias de Eurípides

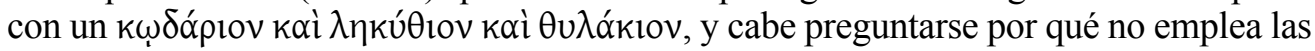
otras dos posibilidades, limitándose a la tediosa repetición de la misma, cuya vis comi$c a$ se le escapa al lector moderno ${ }^{37}$. Cedric H. Whitman (1975:376-78) la encuentra en el hecho de ser «phallus-shaped» el frasquito de aceite del atleta y en las «suggestive possibilities» de la primera sílaba del nombre. Hesiquio y Focio atestiguan la existencia de un término $\lambda \eta \kappa \omega ́$ 'membrum virile' y consta la existencia de un verbo $\lambda \eta \kappa o ́ w \omega$

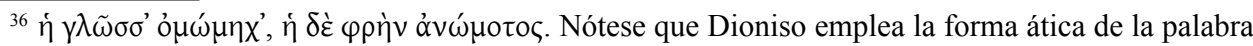
'lengua' y no la jónica que es la que aparece siempre en la tragedia. En los vv. 101-2 de Ranas, según se

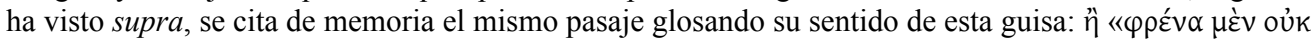

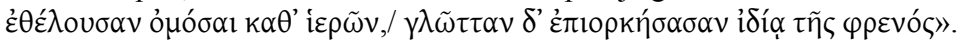

${ }^{37}$ Z.P. Ambrose (1968: 342-345) sugirió que los tres vocablos mencionados formaban un anagrama: Eurípides repetiría siempre lo mismo.
} 
$(=\lambda \alpha \iota \kappa \alpha ́ \zeta \omega)$ que tiene la apariencia de ser un denominativo de dicho término, aunque no se sabe si se usaba en época clásica. Con una falsa silabación, haciendo una pequeña pausa en el comienzo del diminutivo $\lambda \eta \kappa$-ú $\theta$ ıov, se haría fácilmente inteligible al auditorio que lo perdido por los personajes de Eurípides era algo más valioso que un pequeño recipiente de cerámica, dado que el sujeto de los prólogos euripideos elegidos es siempre un personaje masculino: Egipto (Ran. 1206), Dioniso (v. 1211), åvńp (1217), Cadmo (1225), Pélope (1232), Eneo (1238), Zeus (1244).

A la misma conclusión, aunque empleando fuentes distintas, llega John G. Griffith (1975: 380-382). La Suda (vol. 1, 4, p. 262 Adler) cita Thesm. 493 donde aparece el

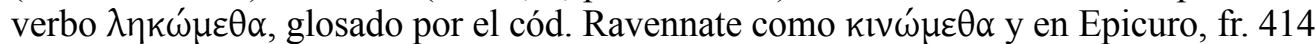
Usener, se encuentra un $\lambda \eta \kappa \eta ́ \mu \alpha \tau \alpha$. Entre las pandillas de golfos callejeros citadas

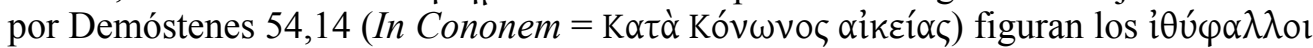

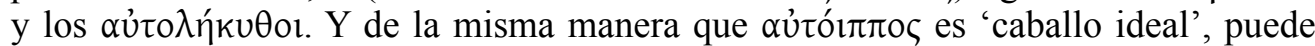

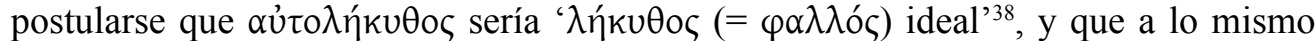
aludiría el nombre de otra pandilla juvenil, la de los Tpı $\beta \alpha \lambda \lambda$ oí (= Tpı $\varphi \alpha \lambda \lambda$ oí), citada en el mismo discurso $(54,39)$. Griffith, hace notar que C. Zink (1883: 22) identificó

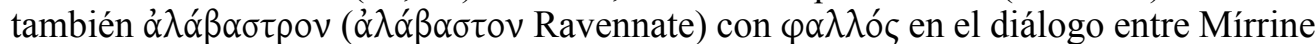

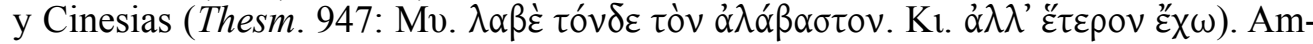
bos trabajos han dado lugar a una polémica que se prolonga hasta el presente siglo.

Apoyan la antedicha interpretación David Sider (1992: 359-364), E. K. Borthwick (1993: 34-37), Eva-Carin Gerö - Hans -Roland Johnson (2002: 38-50). La aceptan con ciertos matices Bruno Snell (1979: 129-133), G. Anderson (1981: 130-132), W. Beck (1981: 234) y M. Robertson (1982: 234). La rechazan R. Guido - A. Filippo (1981: 83-93) para quienes la mencionada muletilla sólo es una crítica de las frecuentes repeticiones a que daban lugar las técnicas de composición de la poesía oral, y D. Bain (1985: 31-37) que no encuentra en el pasaje ningún contenido de carácter

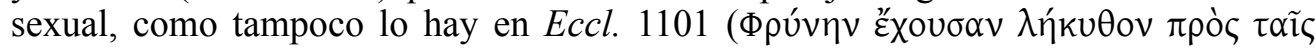

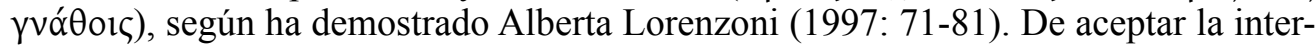
pretación dada por Whitman y sus seguidores al hemistiquio $\lambda \eta \kappa u ́ \theta ı v ~ \alpha ُ \pi \omega ́ \lambda \varepsilon \sigma \varepsilon v$, se podría concluir que por $\kappa \omega \delta \delta$ ápı v quisiera dar a entender Aristófanes el vello púbico y

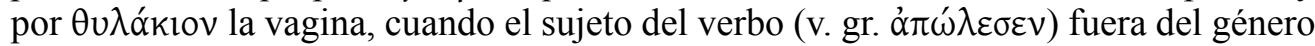
femenino, una mujer o una diosa ${ }^{39}$.

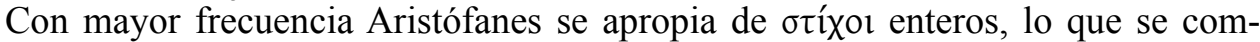
prende perfectamente cuando éstos contienen una frase novedosa o una sentencia de valor universal, de acuñación propia o recibida de una paremia existente. Eurípides, antes de comunicar a Agatón el motivo de su visita, se excusa muy educadamente por ir directamente al grano (Thesm. 177-8): «Agatón, hombre sabio es quien resume

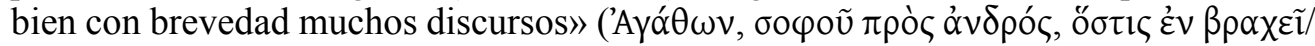

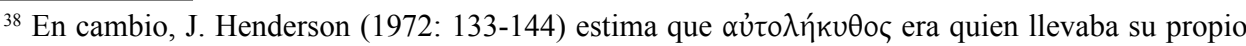
frasquito de aceite para el gimnasio, lo que se estimaba un signo de pobreza. Véase también su réplica (1974: 293-295) a las críticas de R. J. Penella.

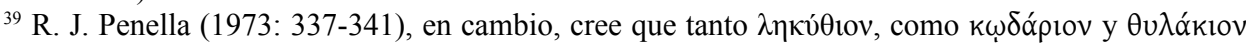
aluden al órtgano sexual masculino. Véase también su réplica (1974: 295-297) a las críticas de su interpretación por J. Herderson. Véase también su contrarréplica (1974: 295-297) a la réplica de J. Henderson. 


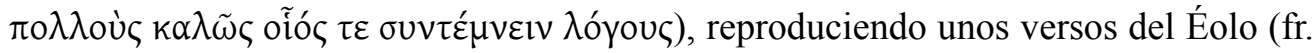
28 Kannicht). En la misma pieza en la larga enumeración de los daños causados por Eurípides a las mujeres al airear en sus tragedias las fechorías femeninas, figura el que ya ningún viejo se quiere casar con una joven por aquella advertencia suya: «Ama del

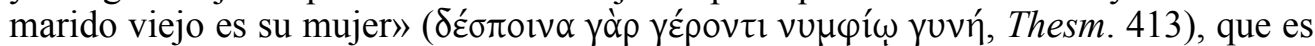
una refección de un verso del Fénix (fr. 804,3 Ka.), alusivo a su vez a una máxima de Teognis (vv. 457-60). En la escena de 'esticostasia' de los versos de Eurípides y Esquilo en la balanza de Dioniso ${ }^{40}$, Eurípides pone en el platillo un imponente dictum (Ran.

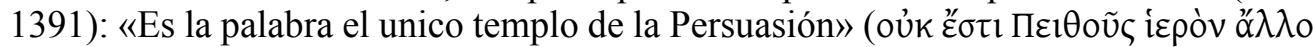

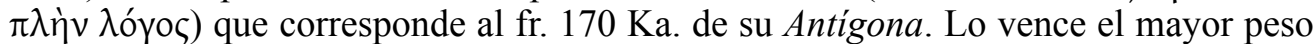

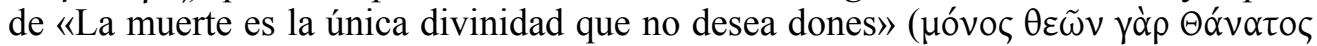

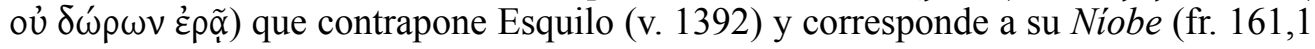
Radt). Por grande que sea el poder de la persuasión, mucho mayor lo es el inapelable e insobornable de la muerte.

Aristófanes parece sentir una especial predilección por la cínica confesión del Hipólito euripideo (v. 612) a la que nos hemos referido anteriormente. De nuevo la vamos a ver citada ahora en Las tesmoforiantes. El Pariente se muestra dispuesto a ayudar a Eurípides, pero quiere tener la garantía de que éste hará lo propio con él, llegado el caso. Eurípides se lo jura «por el éter, residencia de Zeus» (v. 272) recurriendo

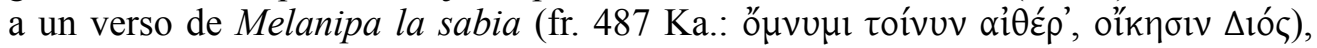
pero, como a su interlocutor no le parezca convincente la fórmula adoptada, repite el juramento poniendo por garantes a todos los dioses a la vez (v. 274). Las dudas del Pariente no se disipan del todo y para evitar cualquier reserva mental en personaje tan marrullero como Eurípides, invirtiendo el orden de palabras del mencionado pasaje del Hipólito (vv. 275-6) , $^{41}$ le amonesta así: «Entonces acuérdate de eso de que "la mente ha jurado, pero la lengua no, y de que yo no te tomé el juramento"», para hacerle ver que el compromiso moral contraído supera a su formulación en palabras y sólo cabe cumplirlo con hechos.

Otro pasaje euripideo que fascina a Aristófanes es el verso 691 de la Alcestis, como claro exponente del egoismo humano. Feres, padre de Admeto, se niega a morir en lugar de su hijo advirtiéndole: «Te place ver la luz, ¿y crees que a tu padre no le place

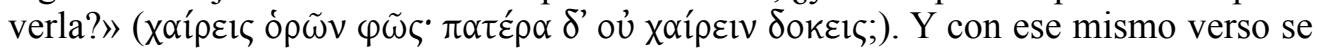
niega el poeta Agatón a ir al Tesmoforion disfrazado de mujer para tomar la palabra en defensa de Eurípides, con una apostilla de cierto regusto euripideo: «Sobrelleva personalmente lo que es tuyo, pues lo justo es soportar las desgracias padeciéndolas,

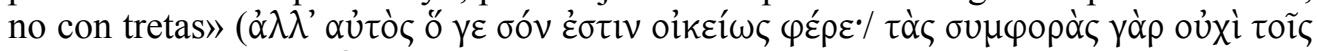

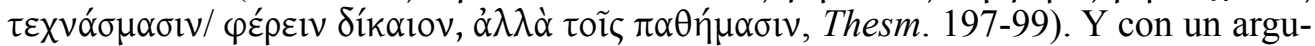
mento similar, aunque invirtiendo el orden generacional, Fidípides justifica la paliza que había dado a su padre por las que de éste había recibido en la niñez: «Los niños

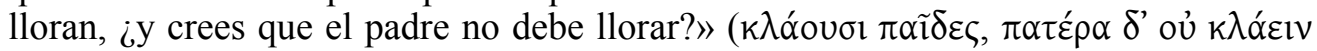
ठокеĩ ; Nubes, 1415).

\footnotetext{
${ }^{40}$ Se trata de un alusión al peso de las moirai del epos aludida en el Memnón de Esquilo, vide. Jacqueline Duchemin (1983: 208-213) y Claudio Tartaglini (1986: 135-140).

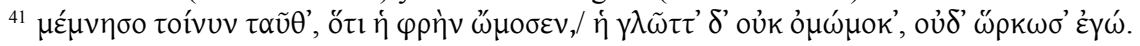


Estos últimos ejemplos muestran lo bien que sabe Aristófanes acomodar el patrimonio euripideo a sus fines. En otros casos no es tan evidente el motivo de la cita o el de su refección. El que en el v. 16 de Caballeros aparezca el v. 345 del Hipólito

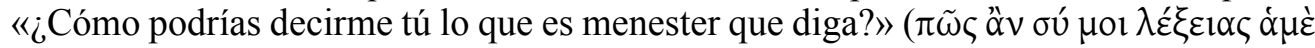

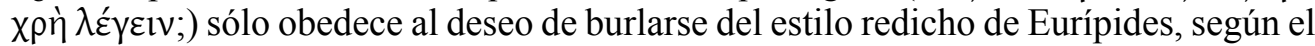
propio Aristófanes avisa poniendo en boca del siervo que hace el papel de Demóstenes la pregunta retórica (vv. 17-18) «¿Cómo lo expresaría de un modo sutil al estilo de Eu-

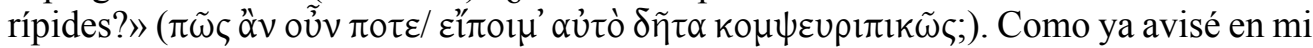
traducción (1995: 244), este aserto obliga a corregir el orden de los versos, colocando el 16 a continuación del v. 18 .

Tras haber liberado a la Paz, Trigeo se despide de Hermes, y llama a su 'hipoescarabajo' para descender montado en él a la tierra. Hermes le comunica ( $P a z 722)$ que

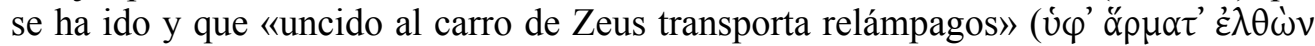

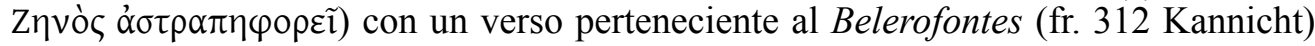
que tal vez se refería a Pégaso. El hipoescarabajo vendría a sustituir en esa función al caballo alado del mito.

El v. 72 de Ranas: «Los que eran buenos ya no viven, y los que viven son malos»

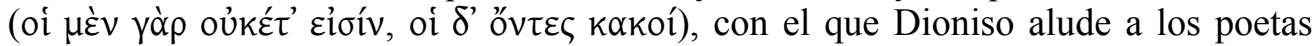
trágicos, procede del Eneo de Eurípides (fr. $565 \mathrm{Ka}$.). Se ignora el motivo de su divulgación como frase hecha del tipo de «ni son todos los que están, ni están todos los que son». El v. 1382 de Ranas: «¡Ojalá! la nave Argo no hubiera emprendido el vuelo»

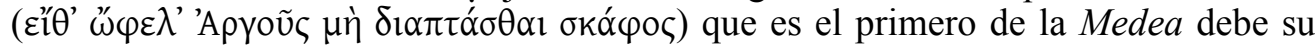
aparición en este lugar al deseo aleatorio de Eurípides, como personaje escénico, de ejemplificar sus prólogos.

La cita del verso euripideo también puede hacerse cambiando un componente del mismo para adecuarlo al sentido exigido por el contexto como en Ran. 282: «Nada hay

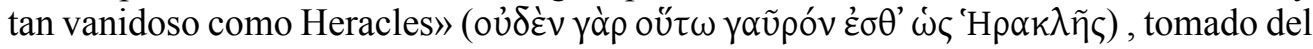
Filoctetes (fr. 788,1 Ka.) sustituyendo el término 'hombre' por el nombre del héroe. En Pax 528 dice Trigeo: «Del hombre enemigo aborrezco el muy enemigo cesto»

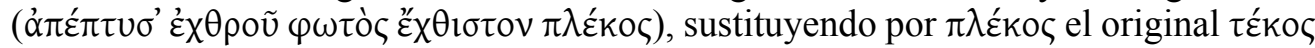
del Télefo (fr. $727 \mathrm{Ka}$.). Mayor rebuscamiento (y peor intención) hay en la réplica airada de Esquilo a una arremetida de Eurípides en Ran. 840: «¿De verdad, hijo de la

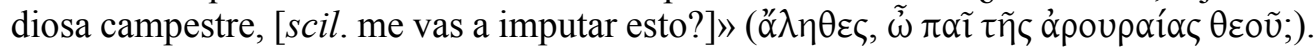
Aristófanes sustituye «la diosa marina» que figura en el fr. $885 \mathrm{Ka}$. de Eurípides como epíteto de Aquiles, hijo de Tetis, por «la diosa campestre», aludiendo al supuesto oficio de verdulera de Cleito, la madre de Eurípides, como hace también en Ach. 457, 478, Equ. 19, Thesm. 387, 456.

Por último, la cita puede condensarse en una mera alusión, bien al protagonista de una tragedia v. gr. Eneo, Fénix, Belerofontes, Télefo, Ino, como en Ach. 418-30, bien a un personaje secundario que figurase en ella, p.e. Tiestes en Las cretenses (Ach. 433), bien sintetizando los hechos más escandalosos que lo caracterizaban como en

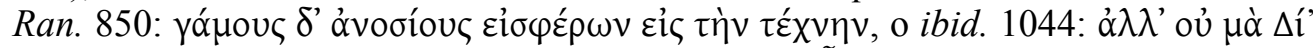

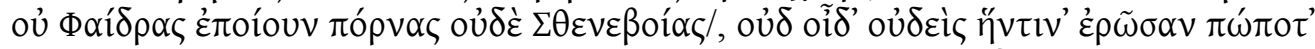

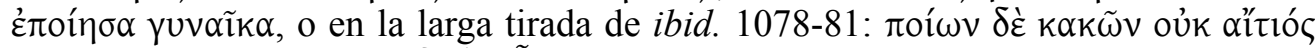

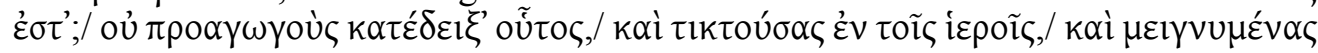




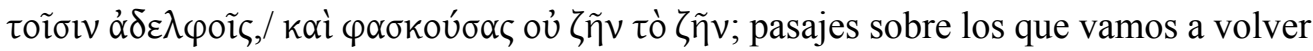
más adelante.

Resumiendo lo dicho: Aristófanes cita (o imita) a Eurípides no sólo por el deseo

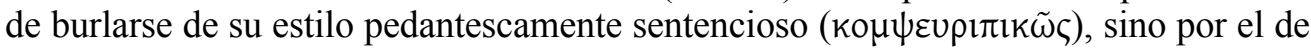
criticar su pensamiento cuando lo considera inmoral o dañino para la sociedad. Y dicha crítica la hace a veces invirtiendo, como se ha visto, el orden de palabras para trastrocar el sentido de lo dicho por el trágico, o construyendo nuevos mensajes sobre el modelo euripideo.

III. Hemos llegado al momento de ocuparnos de las tres comedias en que aparece Eurípides como dramatis persona ${ }^{42}$ : Los acarnienses (425 a. C.), Las tesmoforiantes (411) y Las ranas (404). Ante todo salta a la vista la diferente presentación del personaje en cada una de ellas: en su casa, de visita al domicilio de Agatón, en el Hades discutiendo con Esquilo. En la primera de dichas piezas Diceópolis va a ver a Eurípides para pedirle uno de los atuendos miserables de sus héroes a fin de despertar la compasión de los demotas de Acarnas ante los cuales va a defenderse (Ach. 393-479). Cuando pregunta si está el amo en casa al criado que le abre la puerta, éste lo deja perplejo al responderle que «está dentro sin estar dentro» (oủk Ěv y al explicarle para mayor claridad que: «Su mente, que está fuera recogiendo versecillos, no está dentro, pero él está dentro, con los pies en alto, componiendo una tragedia» (vv. 398-99). Lenguaje tan sofisticado le arranca a Diceópolis la exclamación: «QQué dicha tan grande la de Eurípides, cuando su esclavo responde tan sabiamente

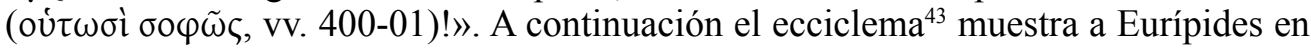
pleno acto creador, sobre un estrado, vestido de harapos y rodeado de máscaras y accesorios teatrales. Enterado del motivo de la visita (v. 415), le ofrece amablemente al visitante la vestimenta andrajosa de «Eneo, el anciano malhadado» (v. 420), la del «ciego Fénix» (421), la del «pobre Filoctetes» (424), la del «cojo Belerofontes» (427), pero Diceópolis le indica que quiere la de uno que «no era Belerofontes, pero también era cojo, pedigüeño, parlanchín, experto orador» (428-9). Eurípides cae en la cuenta de que se trata de Télefo ${ }^{44}$ y le ordena al siervo entregarle su 'andrajario' ${ }^{45}$, indicándole que está «encima de los andrajos de Tiestes, debajo de los de Ino» (432-4). No contento con la ropa, Diceópolis le pide «también lo que hace juego con los andrajos, el gorrillo misio para la cabeza» (438-9) y, una vez travestido de mendigo, declama un pasaje del Télefo euripideo ${ }^{46}$ que cierra, rompiendo la ilusión escénica, con una apostilla crítica a los ardides de Eurípides y a los recursos sofísticos de su estilo ${ }^{47}$ : «Los espectadores han de saber que soy yo, y los coreutas han de estar ahí como imbéciles,

${ }^{42}$ Sobre el tema vide P. Voelke (2004:117-138) y VinicioTammaro (2006:249-261).

${ }_{43}$ Sobre el posible uso paródico de este artilugio, cf. Maria Grazia Bonanno (2006: 69-82).

${ }^{44}$ Sobre Télefo vide Rosa M. ${ }^{a}$ Aguilar (2002: 181-193).

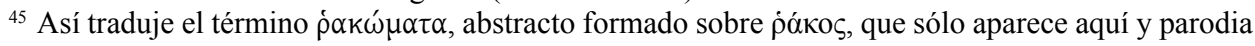
el estilo trágico.

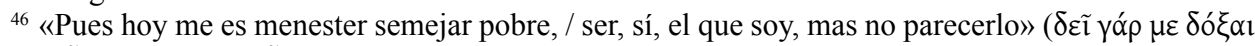

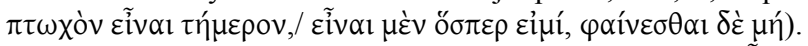

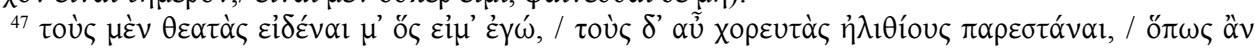

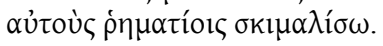




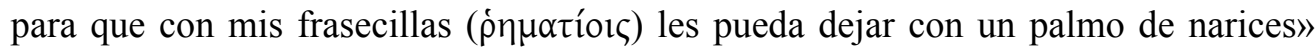
( $\alpha \dot{\tau} \tau o u ̀ s . . . \sigma K \iota \mu \alpha \lambda i ́ \sigma \omega)$.

Al punto de ponerse el harapiento ropaje y calarse el $\pi \imath \lambda i ́ \delta 10 v$, como si se le hubiera transmitido por contagio mágico la vis poetica del trágico, Diceópolis se siente lleno

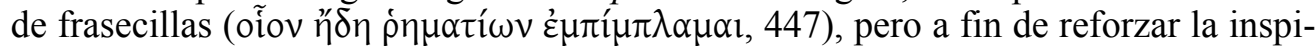
ración quiere completar su apariencia de mendigo. Para ese efecto le pide a Eurípides, primero, «una cachavita apropiada a un mendicante ( $\pi \tau \omega x \imath$ lkov $\beta \alpha \kappa \tau \eta \rho i ́ o v, ~ 448) »$, lue-

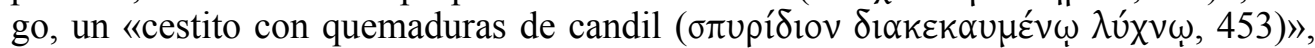

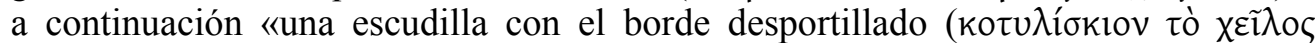

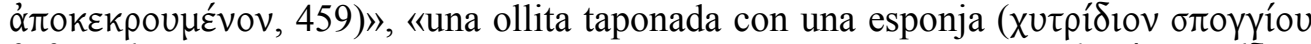

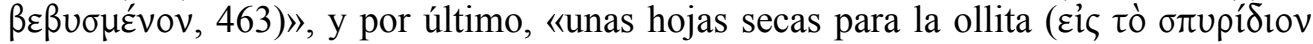

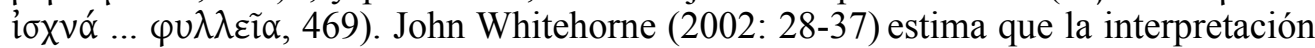
que se da $\varphi \cup \lambda \lambda \varepsilon \tilde{\alpha} \alpha$ como hojas de lechuga es incompatible con el adjetivo ioxvó ('secas') que llevan y estima que pueden ser las hojas de papiro en las que Eurípides ha estado emborronando sus obras. Con ellas Diceópolis no sólo asimilaría la fuerza mágica existente en la harapienta vestimenta, sino también las ideas escritas en las hojas que Eurípides va desechando.

El encuentro de Diceópolis y el trágico en Los acarnienses tiene evidentes analogías con el de Estrepsíades y Sócrates en Las nubes (vv. 126-239), y con el de Eurípides, su Pariente y Agatón en Las tesmoforiantes ( 35-212). En las tres escenas se emplea el ecciclema y las tres van precedidas por la intervención de un criado o un discípulo, que avisa al visitante de que el personaje a quien pretende ver se encuentra inmerso en una actividad intelectual, cual es la reflexión filosófica o la creación poéti$\mathrm{ca}$, que requiere soledad y recogimiento. De ahí la inoportunidad de interrumpir el acto creador, tesitura difícil de describir mediante la palabra, y mucho más aún de visualizar con artificios teatrales. En Las nubes Aristófanes se sirve de las diversas posturas de los discípulos para indicar sus respectivas investigaciones (186-216) y para mostrar cuál era la de Sócrates, Aristófanes lo presenta con la mechané colgado en una cesta y pone en su boca aquella famosa, aunque ambigua, explicación de «ando por el aire y

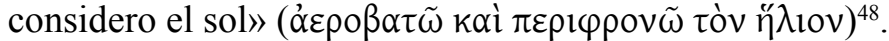

Las convenciones teatrales empleadas en las otras dos piezas son de índole diferente y atañen a la postura y a la vestimenta. En Los acarnienses Eurípides aparece sentado o reclinado en una especie de estrado lo que provoca la admiración de Diceópolis: «¿Compones con los pies en alto (ảv $\alpha \beta \alpha ́ \delta \eta v)$, pudiéndolo hacer con ellos en el suelo? Con razón creas personajes cojos? Pero, ¿por qué te has puesto esa vestimenta lamentable, esos harapos sacados de alguna tragedia? (410-13)». Evidentemente Eurípides está en trance de identificación mimética ${ }^{49}$ con alguno de sus personajes, como también lo está Agatón cuando aparece en Las tesmoforiantes, reclinado en un lecho y con ropas de mujer, mientras recita alternativamente las partes del corifeo y las de un coro femenino. Así se lo explica al Pariente: «Yo llevo la vestimenta de acuerdo con

${ }^{48}$ El verbo $\pi \varepsilon \rho \iota \varphi \varphi \rho v^{2} \tilde{v} v$ tiene el doble sentido de 'considerar a fondo' y 'menospreciar', en el que lo entiende Estrepsíades. Sobre este pasaje, véase L. Gil (1988: 211-18).

${ }^{49}$ Sobre el tema, vide Elena Mazzacchera (1999: 205-224), Rosella Saetta Cottone (2003: 445-469) y John Given (2007: 35-51). 
mi intención, pues el poeta ha de adaptar su forma de ser al drama que debe componer. Por ejemplo, si compone acciones de mujer, su persona debe compartir la forma de ser de éstas» (146-150). Pero en su caso el ecciclema no ha funcionado a requerimiento de los visitantes inoportunos, sino por imposición de la misma tarea creadora en el poeta. El mecanismo no presenta al poeta en el interior de su vivienda, sino que lo saca al aire libre en busca de calor, según apunta su criado: «Como es invierno no es fácil retorcer las estrofas, si no sale al sol a la puerta de casa» (vv. 67-69) ${ }^{50}$. Y como antes, aquí también la imaginación de John Whitehorne se dispara. Atendiendo a lo dicho por

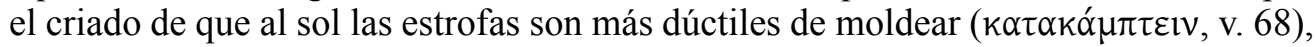
sugiere que Agatón, en vez de recitar de memoria las partes del texto, las iría leyendo de unas tablillas de cera o de unas 'hojas' de papiro. En resumidas cuentas, tanto en el caso de las $\varphi u ́ \lambda \lambda \varepsilon \imath \alpha$ de Los acarnienses como en Las tesmoforiantes, habría una variante del simbólico rollo de papiro de las artes plásticas ${ }^{51}$. Aristófanes emplearía las mismas señales visuales que los escultores y pintores de vasos venían empleando para representar el trabajo invisible de la mente. Pero a Whitehorne se le podría objetar que

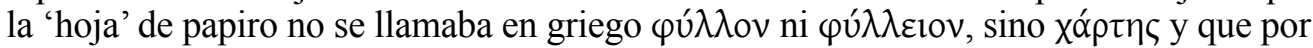
кó $\lambda \lambda \eta \mu \alpha$ se entendía el pegamento con que se unían unas $\chi \alpha ́ \rho \tau \alpha$ con otras para for-

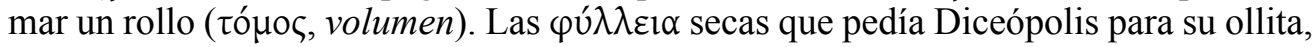
evidentemente no eran de lechuga para hacer una ensalada, sino hojas de laurel o de cualquier planta aromática para condimentar un guiso o una sopa.

Dicho esto, antes de considerar Las ranas, hay que decir dos palabras sobre el Eurípides que aparece en Los acarnienses y en Las tesmoforiantes. El examen de estas piezas obliga a reconocer que no se percibe en ellas una marcada hostilidad contra su persona ${ }^{52}$. El trágico en la primera atiende con amabilidad todas las peticiones de Diceópolis y le aguanta sus impertinencias (cf. vv. 457,478). Las críticas en esta pieza apuntan a la selección del legado mítico por parte de Eurípides y a su forma de tratarlo. Son de carácter estrictamente literario. Los ideales heroicos de la cultura del pundonor que dieron origen a la saga y el mito griego, parecen haber ha sido reemplazados en Eurípides por los valores 'pequeño-burgueses' (sit venia verbo) propios de la demo-

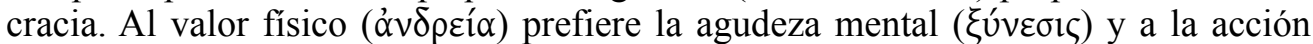
directa $(\pi \rho \tilde{\alpha} \xi 1 \varsigma)$, la maquinación inteligente ( $\mu \eta \chi \alpha \nu \eta ́)$. Los protagonistas de sus tragedias suelen aparecer hundidos en la enfermedad y la pobreza, donde los han precipitado los golpes de fortuna o el castigo de los dioses. Los procedimentos ( $\mu \eta \chi \alpha v \alpha i ́)$ a que recurren para superar sus miserias distan de ser proezas épicas y en ocasiones semejan artimañas truhanescas. Así el chantaje de Télefo cuando pone en juego la tierna vida del infante Orestes para conseguir sus fines. Una vil treta cuyas posibilidades cómicas desarrolló Aristófanes en Los acarnienses y en Las tesmoforiantes. Fallos semejantes en los argumentos y en los motivos particulares de las piezas no logran, a juicio de

\footnotetext{
${ }^{50}$ Sobre la diferente manera de entender la creación poética de Eurípides y Agatón, vide Dina Micalella (2005: 188-194).

${ }^{51}$ En una figura roja de Duris (ca. 500-460 a. C.) aparece un maestro abriendo un rollo de papiro, otro vaso también de figuras rojas ( $c a$. 440) muestra a Safo desenrollando un papiro que contiene uno de sus poemas. Para el simbolismo del rollo de papiro y del códex desde la época clásica al primitivo cristianismo, remito a L. Gil (1995).

${ }^{52}$ Sobre Eurípides como personaje cómico vide Vinizio Tammaro (2006: 249-261).
} 
Aristófanes, remediarlos ni encubrirlos los recursos del lenguaje euripideo: los dichos sentenciosos, las antítesis y los términos abstractos o poéticos. En resumidas cuentas sólo expresan ideas más bien vulgares.

La presentación de Eurípides en Las tesmoforiantes destaca su condición de poeta бофós. Sirven para ponerla de relieve las distinciones que establece entre 'ver' (ópãv) y oír (åkoúcıv) y la breve explicación sobre la función del 'eter' en el totum revolutum primigenio (vv. 5-18) que le da a su Pariente mientras le va conduciendo a la casa del poeta Agatón. Pero la 'sabiduría' no le tranquiliza sobre el juicio al que le van a someter las mujeres en el Tesmoforion de Atenas por difamarlas en sus tragedias (v. 85).

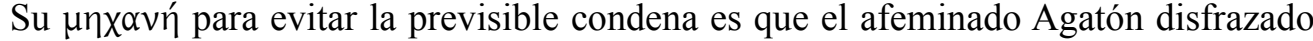
de mujer asista a la festividad y tome la palabra en su defensa. Pero el poeta se niega, como hemos visto, a secundar sus planes con las palabras de Feres a su hijo Admeto en la Alcestis euripidea (v. 691). El Pariente se presta entonces a reemplazarlo en ese

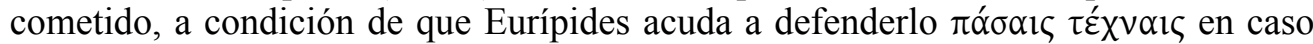
de necesitar su ayuda. El trágico jura que así lo hará (vv. 272-6), y en su honor debe decirse que cumple escrupulosamente su palabra.

Descubierto el Pariente, fracasado su intento de repetir la treta del Télefo (590-

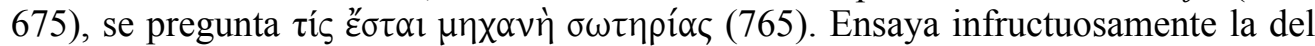
Palamedes (770), pero decide por último emplear la de la Helena ${ }^{53}$. Eurípides aparece en escena representando el papel de Menelao cuando se encuentra en Egipto con su esposa (vv. 871-924). Pero le obliga a retirarse la aparición de un prítanis y un arquero que se llevan detenido al Pariente (v. 924). Cuando éste regresa a escena sujeto al tablón del apotympanismós y vigilado por el arquero escita, de nuevo se presenta Eurípides caracterizado de Perseo (v. 1098) con la intención de llevarse al Pariente que con ello se encuentra en la situación de representar el papel de Andrómeda encadenada ${ }^{54}$, pero, como comprueba que todos los intentos de persuadir al bárbaro guardián resul-

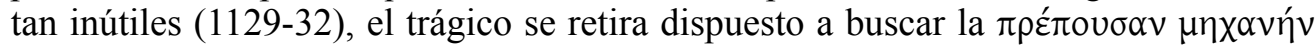
a su obtusa mente. Poco después reaparece disfrazado de alcahueta, en compañía de una bailarina y de un flautista, y de esta guisa le propone al coro hacer las paces con las mujeres y no volver a difamarlas si le permiten llevarse consigo a su Pariente. El corifeo acepta el pacto y señalando al escita que está dormitando le dice «trata tú de convencer a ése» (1170-71). Gracias a los encantos de la bailarina consigue Eurípides

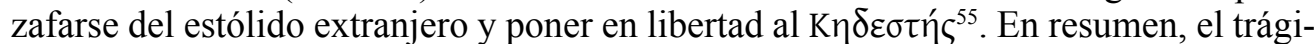
co en esta pieza desempeña el papel positivo del ravoũpyo en el cuento popular. A la postre consigue librar al Pariente del embrollo en que lo ha metido. Le sirve además a Aristófanes de pretexto para emplearse a fondo en la parodia de las tragedias euripideas más recientes, la Helena y la Andrómeda.

Llegamos al momento de ocuparnos de Las ranas, una pieza construida en torno

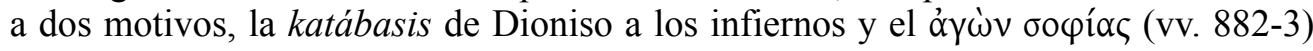

\footnotetext{
${ }^{53}$ Sobre la parodia de la Helena y la Andrómeda euripideas, vide P. Rau (1975: 339-54).

${ }^{54}$ Sobre la parodia de la Andrómeda en Tesmoforiantes remito a R. Moorton (1987: 434-36) y sobre todo a G. Mastromarco (2008: 177-188).

${ }^{55}$ Cf. sobre este pasaje (Thesm. 1174ss.) vide Edith M. Hall (1989: 38-54) y Marta Flora di Bari

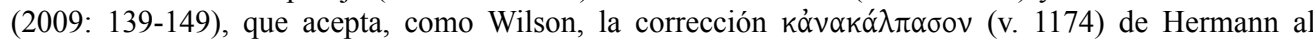

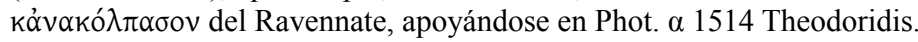


entre Eurípides y Esquilo en el que divinidad tutelar de la tragedia actúa de árbitro. El primer motivo tenía ciertos antecedentes en la comedia. El propio Aristófanes en el

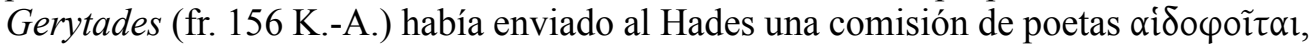
Sannirión, Meleto y Cinesias, en representación respectivamente de la comedia, la tragedia y la poesía cíclica. Ferécrates presentó en los Krapatalói a Esquilo defendiendo su arte en el Hades o devuelto a la superficie de la tierra. En nuestra pieza la katábasis comprende el prólogo, la párodo de los bienaventurados, la parábasis y algunas escenas cómicas. Dioniso desciende al Hades en busca de Eurípides (vv. 68, 80) porque ya no queda ningún buen poeta cómico con vida (v. 72), lo que plantea el interrogante de por qué no quiere traerse consigo a Sófocles, considerado el príncipe de los poetas. Y no cabe a nuestro juicio respuesta más satisfactoria que la de Wilamowitz (19753: 357-363) quien supuso que en el momento en que Aristófanes compuso las líneas generales de su comedia Sófocles, muerto poco después de Eurípides, todavía estaba con vida, lo que le obligó al comediógrafo a hacer pequeñas correcciones en su obra antes de su representación (Leneas del 404 a.C.). Entre ellas el que Sófocles no ocupara en el Hades el trono de la tragedia por habérselo cedido amablemente a Esquilo y el que estuviera dispuesto a disputárselo a Eurípides si resultaba vencedor en su certamen con Esquilo (vv. 786-794).

El segundo motivo de Las ranas, el agón entre ambos trágicos, con un antecedente tradicional en la disputa entre Homero y Hesíodo ${ }^{56}$, se inicia tras un canto del coro en el verso 830 y dura hasta el final de la pieza (v. 1553). Es significativo el hecho de que, cuando se le pide a Dioniso que decida cuál de los dos poetas quiere llevarse a la superficie de la tierra, el dios conteste: «Amigos, tampoco yo voy a emitir un juicio, pues no voy a enemistarme con ninguno de los dos. A uno lo considero sabio, el otro me agrada» (vv. 1411-13). Esto implica que desde un punto de vista estrictamente literario el dios los pone a ambos en pie de igualdad por lo cual le resulta muy difícil la elección. Al recordarle entonces Plutón que habría realizado su viaje en vano y preguntarle para qué fue a buscar un poeta al Hades, el dios responde: «Para que la ciudad, puesta a salvo de peligros, celebre sus coros. Así que a aquél de los dos que vaya a dar un buen consejo para la ciudad, tengo decidido llevarlo conmigo» (vv. 1418-21). Acto seguido les pregunta su opinión sobre Alcibíades. Y en este momento se produ-

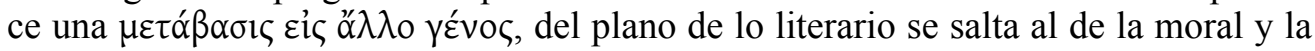
política, entrando en juego consideraciones parecidas a las de la parábasis ${ }^{57}$. Atenas había preparado con enorme esfuerzo la última gran flota que habría de decidir en el Helesponto su suerte y Alcibíades estaba disponible en Tracia para asumir el mando. La opinión en Atenas se dividía. Se le añoraba, pero también se le odiaba. Interesaba, por tanto, conocer cuál era el respectivo sentir de tan influyentes autores.

\footnotetext{
${ }^{56}$ Sobre el tema vide Helmut Erbse (1975: 45-60) y Marina Cavalli (1999: 83-105).

${ }^{57}$ Como ha visto muy bien Pascal Thiercy (2010: 675) a Las ranas subyace un silogismo voluntarista, similar al de todas las piezas de Aristófanes, del tipo: a) La cultura ateniense ha muerto tras morir sus grandes poetas. b) Dioniso puede traer del Hades al mejor de sus poetas. c) Éste hará revivir la cultura ateniense.
} 
Eurípides manifiesta sin rodeos su rechazo al político ${ }^{58}$ mediante una doble antítesis

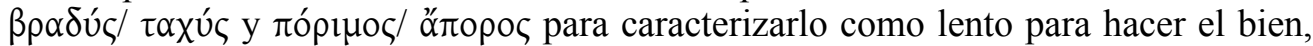
rápido para hacer el mal, fértil en recursos para beneficiarse a sí mismo, carente de ellos para beneficiar a la ciudad (vv. 1427-29). Esquilo, en cambio, aunque con cierta precaución, se declara partidario de Alcibíades. No hay que criar un cachorro de león

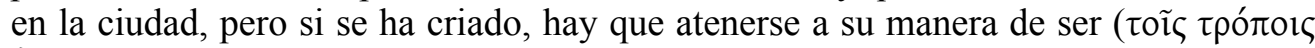

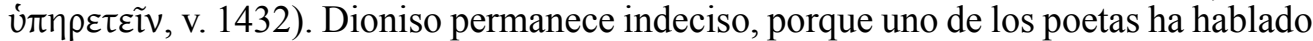

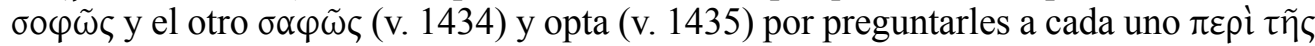

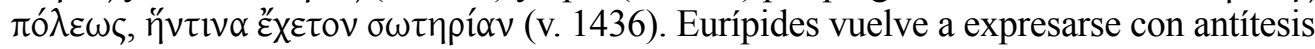
a la manera de los sofistas. La salvación de la ciudad estriba en considerar como digno de crédito lo que ahora no lo es (vv. 1442-3), explicándolo a continuación como quitar la confianza del demos a quienes ahora la tienen y recurrir a quienes ahora no se recurre (vv. 1446-8). Esquilo pregunta entonces a Dioniso, que como recién venido de Atenas tiene buena información, si la ciudad cuenta con políticos honrados y los estima, y al enterarse de que no es así, porque odia a los honrados y recurre a los que no lo son, aunque tampoco le gusten, replica que la ciudad en ese caso no tiene salvación posible. Preguntado de nuevo por Dioniso por el remedio que propone para ella, responde que considerar como propia la tierra de los enemigos y, a la inversa, como de ellos la propia, y también considerar las naves como riqueza y la riqueza pobreza (vv. 1463-5). Pero esto no era otra cosa sino volver a la política de Pericles ${ }^{59}$, a saber, dejar la tierra del Ática en manos de los enemigos y devastar con la flota sus zonas costeras, aunque con una pequeña corrección, la de estimar como riqueza la pobreza, lo que significaba no malgastar el dinero de la ciudad en sueldos públicos para no dejar exhausto el erario. Puesto ya en situación de decidir, Dioniso citando a medias el famoso verso del

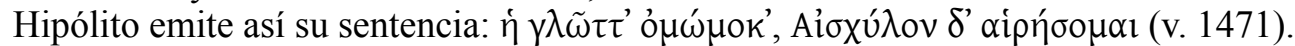

Pese a las protestas de Eurípides, la divinidad patrona de la tragedia fundamenta su fallo atendiendo a la doble vertiente que hay que considerar en todo poeta trágico, su capacidad creativa como tal y la calidad ética de sus obras. Dicho en las propias

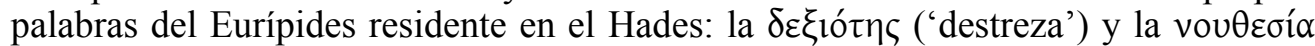
('consejo', Ran. 1009). Aristófanes estima, por un lado, que la tragedia (y también la comedia) es como una emanación de la personalidad creadora, algo así como un parto de sentencias, pensamientos y expresiones adecuadas a los mismos $(\mu \varepsilon \gamma \alpha \dot{\alpha} \lambda \omega v$

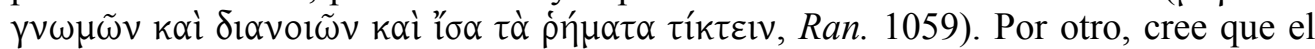

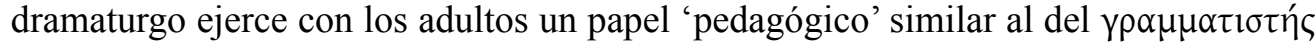

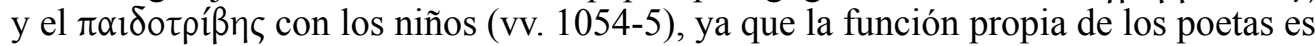
«hacer a los hombres mejores en las ciudades» (Ran. 1009-10) ${ }^{60}$. Y en esta convicción despide el corifeo a los actores en el éxodo: «Desead primero, divinidades subterráneas, un buen viaje al poeta que se va en su ascenso a la luz, y a la ciudad inspiraciones buenas de grandes bienes. Pues así acabaríamos definitivamente con grandes

${ }^{58}$ E. Delebecque (1967: 354-362) cree adivinar un ataque a Alcibíades en el Agamenón de Ifigenía en Áulide y en el Dioniso de Las bacantes de Eurípides. Sobre la figura del político en el teatro ateniense, vide Richard F. Moorton (1988: 345-59) y Michael Vickers (1989: 41-65, 267-299).

${ }^{59}$ Sobre la propuesta política, vide A. H. Sommerstein (1974: 24-27) y Maurizio Sonnino (1999: 65-97).

${ }^{60}$ Sobre este propósito vide David Bouvier (2004:9-26). 
sufrimientos y con terribles choques de armas» (vv. 1528-32). No cabe, pues, duda alguna de que desde el punto de vista tanto de la política como de la moral nuestro autor estimaba que Esquilo era superior a Eurípides, pero ¿ocurría lo mismo desde el punto de vista literario? Permítaseme que antes de dilucidar esta cuestión, me ocupe primero de lo que parece obvio.

Aristófanes ya de entrada no juega limpio ni en la manera de presentar los contendientes, ni la disputa entre ambos, ni en las invocaciones a los dioses que cada uno hace antes de entrar en liza. Esquilo se dirige a su rival como «hijo de la diosa campestre, recolector de monsergas, creador de mendigos, remendón de harapos» (vv. 840-2), «creador de cojos» (v. 846), «recolector de monodias cretenses e introductor de nupcias impuras en el arte» (vv. 850-1). En suma, con un puñado de epítetos despectivos que descalifican la obra entera de Eurípides. El coro anuncia el debate (vv. 814-29) con términos tomados de la épica como si fuera un combate singular entre ambos trágicos.

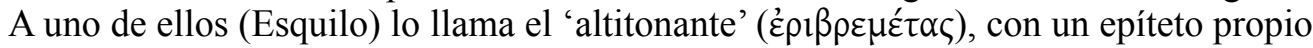
de Zeus $(I l .13,624)$ y que Píndaro aplica al león $(I s t .4,50)$. De sus frases dice que

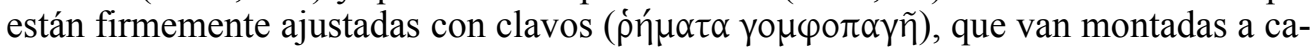
ballo (i $\left.\pi \pi \circ \beta \alpha \mu_{\mu} \sigma \alpha\right)$, que son la expresión de un arquitecto ingenioso ( $\varphi \rho \varepsilon v o \tau \varepsilon ́ k \tau o v o \varsigma$

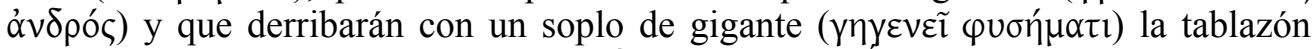

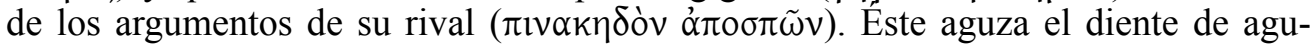

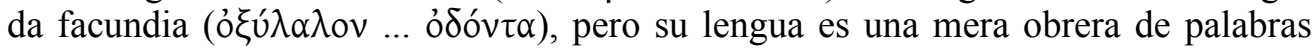

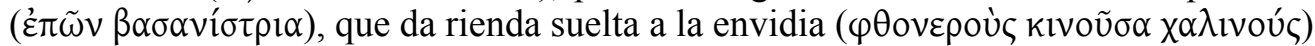

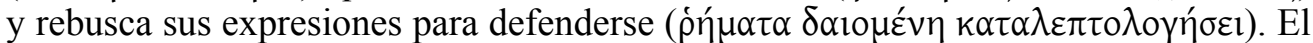
coro invoca la presencia en el certamen de las nueve Musas (vv. 875-84) y Dioniso invita a los contendientes a elevar una plegaria a sus divinidades protectoras. Esquilo invoca a Deméter (886-7) y Eurípides, con esa facilidad innata de los griegos para las personificaciones y la creación de 'divinidades instantáneas' (Augenblickgötter), hace lo mismo de esta guisa: «Éter, nutrición mía, torbellino de la lengua, inteligencia y narices olfateadoras, que demuestre bien los argumentos que toque» (vv. 892-4) ${ }^{61}$.

En cuanto a la función 'pedagógica', Esquilo reivindica haber contribuido a fomentar el espíritu guerrero con los Siete contra Tebas (v. 1021) y el deseo de emular a los héroes con Los persas (v. 1026), como demostró en Sicilia la muerte gloriosa de Lámaco (v. 1039). El poeta debe ocultar el mal y presentar el bien (1053-55), enseñando siempre algo de utilidad como todos los grandes poetas hicieron, Orfeo con sus iniciaciones mistéricas, Museo con sus curaciones y oráculos, Hesíodo con los

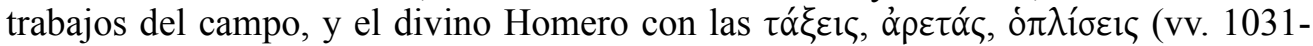
36). En cambio, Eurípides llevó a sus tragedias a alcahuetas como la nodriza de Fedra en el Hipólito, a mujeres pariendo en los templos como Auge, sacerdotisa de Atenea y madre de Télefo, en la pieza intitulada con su nombre, a hermanas copulando con sus hermanos, como Cánace con Macareo en el Éolo, o a hembras diciendo que vivir es no vivir como la sabia Melanipa (vv. 1079-82) ${ }^{62}$. Ya con anterioridad a la protesta

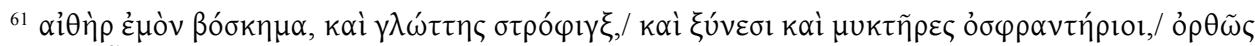

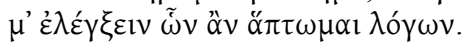

${ }^{62}$ Como habla para un público entendido, Aristófanes no explicita ni los títulos, ni las circunstancias particulares de la cada una de las piezas.
} 
airada de Eurípides: «Y qué daño causan a la ciudad, grandísimo miserable, mis Estenebeas?» (v. 1049), su rival había replicado: «Porque indujiste a nobles esposas a beber la cicuta avergonzadas por tus Belerofontes» (v. 1050).

Por boca de Esquilo el cómico acusa a Eurípides de haber sustituido las grandes figuras de la tradición griega por otras secundarias más próximas a las personas de carne y hueso, de haber reemplazado los grandes problemas de carácter general por los particulares de cada día, de haber sustituido el mito por lo cotidiano y medido lo heroico por el rasero común de los ciudadanos. Paralelamente ha rebajado el lenguaje, pues «las grandes sentencias y pensamientos por fuerza engendran palabras iguales»y «es natural que los semidioses empleen términos más elevados» (vv. 1058-60). Eurípides ha enseñado a la gente a pensar, a discutir, a sospechar maldades, a rebelarse (vv. 956-7). De ahí que las palestras hayan quedado vacías de jóvenes, y que los marineros en vez de aplicarse al remo repliquen a sus jefes y cometan en tierra tropelías (vv. 1069-70). Tampoco ha sido pequeño el daño que han causado sus reyes revestidos de harapos. Ahora los ricos se niegan a ser trierarcos y se cubren de andrajos para simular que son pobres (vv. 1063-64). Pero lo peor de todo es que con su proceder Eurípides ha emitido la sentencia de muerte para la tragedia como género literario. Esto es lo que en el fondo significa la afirmación de Esquilo: «Quisiera no discutir aquí, porque el debate no se presenta en condiciones de igualdad para los dos». Dioniso le pregunta: «¿Por qué razón?». Y su respuesta es: «Porque la poesía no ha muerto conmigo, y con él sí, de suerte que podrá hablar» (vv. 866-69), a saber, como difunto que es, de algo que también está muerto.

Como si intuyera la evolución posterior del teatro griego, Aristófanes presentía que la conducta de los personajes euripideos en realidad era cómica, tanto en sus pasiones, vulgares en el fondo por muy ardientes que fuesen, como en sus mezquinas intrigas. Ridículamente cómica es la grandilocuente monodia de Glice que compone Esquilo a imitación de las de su colega (vv. 1331-64) sobre motivo tan nimio como el robo de un gallo. La tragedia ciertamente acabó con Eurípides y sus progresos como género los heredó la comedia nueva ${ }^{63}$ que trasladó los afectos y la intriga del universo del mito al mundo de lo cotidiano. De lo que Aristófanes no se daba cuenta era de que con la tragedia desaparecía también la comedia antigua para transformarse en algo muy distinto del género que él había conocido y egregiamente cultivado.

Que Aristófanes fue muy consciente de los progresos en la técnica teatral de Eurípides es lo que me interesa recalcar en lo que sigue. Dichos progresos se manifiestan en la crítica que amparándose en el trágico hace Aristófanes del teatro de Esquilo. Eurípides, que se muestra dispuesto a discutir «en los diálogos, en los cantos, en la

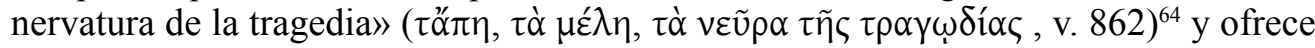
sus obras para someterlas a examen, critica ante todo los caracteres de Esquilo y su forma de expresarse. Los personajes de sus obras son «agrestes, de lenguaje atrevido, desenfrenado, descomedido, sin contención, ajeno al cicunloquio y amontonador de

${ }^{63}$ Para las semejanzas de la comedia nueva con la tragedia de Eurípides, cf. C. James (1969: 27-31)

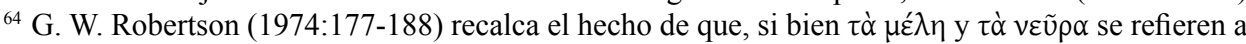

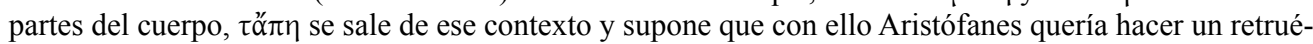
cano con $\tau \grave{\alpha}$ đén (los phalli). Pero la seriedad del pasaje excluye un double entendre obsceno. 
palabras pomposas» (vv. 836-39). En los prólogos de sus tragedias se revela como

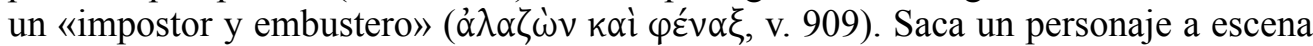
cubierto con un velo y así lo deja durante largo tiempo para despertar la curiosidad del espectador (vv. 911-13). Amontona después series de cantos y mantiene en silencio a los actores (vv. 914-15). Luego, cuando la pieza va ya por su mitad, suelta «una docena de palabras del tamaño de un buey, altivas y empenachadas, y algunas expresiones tremebundas que los espectadores desconocen» (vv. 924-5). Frente a esto Eurípides se jacta de dejar bien claro desde un primer momento de qué va a tratar la obra (v. 945), de repartir equilibradamente las partes dialogadas y las corales (v. 958-50), de aliviar al lenguaje de ampulosidades y términos incomprensibles (vv. 937-48), y de acrecentar con monodias las partes cantadas. Unos progresos en suma en el arte que Aristófanes como hombre de teatro y no ajeno a las enseñanzas de la sofística sabría apreciar.

Con buena parte de lo dicho quizá Aristófanes se mostraría de acuerdo. Pero mucho me temo que ya no lo estaría tanto con algunos de los asertos que atribuye al Eurípides de Ranas. Por ejemplo, ése de que para no dejar a ningún personaje inactivo en sus obras daba la palabra al marido y a la mujer, al amo y al esclavo, a la vieja y a la joven y que proceder así es lo más democrático (vv. 948-50). O este otro de que enseñó a la gente a «reflexionar, a ver, a comprender, a maquinar, a sospechar, a darle vueltas a todo con la mente» (vv. 956-7). O este último de que introdujo en sus obras las cosas domésticas, para poder someterse a la crítica del pueblo llano, buen conocedor de ellas, y que, para no apartarlo de la sensatez dejándolo perplejo (vv. 959-64), siempre rehuyó llevar a escena «personajes como Cicno o Memnón en potros de arneses con cascabeles».

\section{REFERENCIAS BIBLIOGRÁFICAS}

Aguilar, R. M. a (2002), «La figura de Télefo en la literatura y en el arte griegos», $C F C(G) 13$ : 181-182.

Ambrose, Z. P. «The lekythion and the anagram of Frogs 1203», AJPh 89: 342-345.

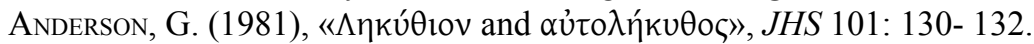

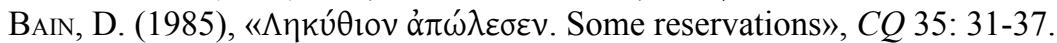

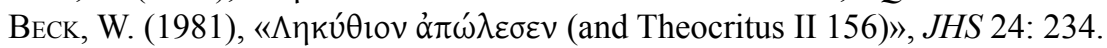

Bergson, L. (1953), «The Omitted Augment in the Messengers' Speeches of Greek Tragedy», Eranos 51: 121-128.

Bonanno, M. ${ }^{a}$ G. (1987), «П $\alpha \rho \tau \tau \alpha \gamma \varphi \delta \delta ́ \alpha$ in Aristofane», Dioniso 57: 135-167.

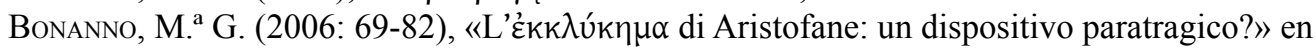
Medda, E., Mirto, M. ${ }^{a}$ S., Pattoni, M. ${ }^{a}$ P. Eds.(2006).

Borthwick, E. K. (1993), «Autolekythos and lekythion in Demosthenes and Aristophanes», LCM 18: 34-37.

Bouvier, D.(2004), «"Rendre l'homme meilleur!” ou Quand la comédie interroge la tragedie sur sa finalité: à propos des Grenouilles d'Aristophane», EL, 9-26.

Casanova, A., Desideri, P. Eds. (2003), Evento, racconto, scrittura nell'antichità classica. Atti del convegno internazionale di studi, Firenze, 25-26 Novembre 2002, Firenze 2003. 
Cavalli, M. (1999), «Le Rane di Aristofane: modelli tradizionali dell' agone fra Eschilo ed Euripide», en ConCA, F. (1999: 83-105).

CERri, G. (1969), «Il passaggio dalla cultura orale alla cultura di communicazione scritta nell'età di Platone», QUCC 8: 119-133.

Conca, F. Ed. (1999), Ricordando Rafaelle Cantarella: miscellanea di studi a cura di, Milano.

Cortés Gabaudan, F., Méndez Dosuna, J. V. (2010), Dic mihi, Mvsa, Virvm. Homenaje al Profesor Antonio López Eire, Salamanca.

Coulon, V. (1957), «Thesmophoriazusen 1015-1055», RhM 100: 186-198.

Degani, E. (1983³), «La poesia parodica-Appunti», en Poesia parodica, Bologna.

Delepierre, O. (1890), La parodie chez les Grecs, les Romains et les modernes, London.

Delebecque, E (1967), «Alcibiade au théâtre d'Athènes à la fin de la guerre du Péloponnese», Dioniso 41: 354-362.

DelNIERI, F. (2000), «Elementi di paratragedia nelle Eroi di Aristofane», EIKASMOS 11: 107-114.

Di BARI, M. Fl. (2009), «Una Cerbiatta 'equina' (Ar. Th. 1174, 1210s.)», EIKASMOS 20: 139-149.

Di Marco, M. (2009:119-146)., «La Musa di Euripide: sulla parodia dell' Ipsipile euripidea nelle Rane di Aristofane», en Di Marco, M., Tagliaferro, E. Eds.(2009).

Di Marco, M., Tagliaferro, E. Eds., Semeion philias: studi di letteratura greca offerti ad Agostino Masaracchia, Roma, 2009.

Dover, K. J.(1970), «Lo stile di Aristofane», QUCC 9: 7-23.

Duchemin, J. (1983), «La pesée des destins», en Jouan, F. Ed. (1983: 208-213).

Erbse, H. (1975), «Dionysos' Schiedspruch in den Fröschen des Aristophanes» en $\Delta \omega ́ p \eta \mu \alpha$ Hans Diller zum 70. Geburtstag. Dauer und Überleben des antiken Geistes, Athen,1975: 45-60.

FunAioli, M. ${ }^{\text {a }}$ P. (2007), «Gli Ucelli di Aristofane (vv. 1565-1693) e le Troiane di Euripide (vv. 1-97): un nuovo caso di paratragedia», Dioniso (N.S.) 6: 98-107.

Gerö, E.-C., Johnson, H.-R. (2002), «A Comment on the Lekythian-scene in Aristophanes' Frogs», Eranos 100: 38-50.

GiL, L. (1988), «La escenificación de la creatividad intelectual en la comedia aristofánica», en Gil, L. , Aguilar, R. M.', Pastor, M. Eds. (1988: 211-218).

GiL, L. (1995), La palabra y su imagen. La valoración de la obra escrita en la Antigüedad, Madrid, 1995.

GiL, L. (1995), Aristófanes. Comedias I. Los acarnienses - Los caballeros. Introducciones, traducción y notas. Madrid.

Gil, L., Aguilar, R. M. ${ }^{\text {a }, ~ P A s t o r, ~ M . ~ E d s . ~(1988), ~ C o r o l l a ~ C o m p l u t e n s i s . ~ H o m e n a j e ~ a l ~ p r o f e s o r ~}$ José S. Lasso de la Vega, Madrid, 1988.

Given, J. (2007), «The Agathon Scene in Aristophanes' Thesmophoriazusae», SO 82: 35-51.

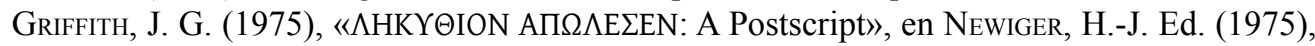
380-382.

Guglielmino, F. (1928), La parodia nella commedia greca antica, Catania.

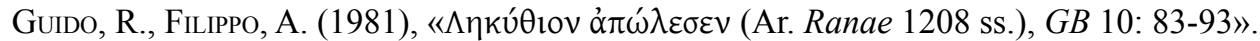

Hall, E. M. (1989), «The archer scene in Aristophanes' Thesmophoriazusae», Philologus 133: $38-54$.

Handley, E. W. - Rea, J. (1957), The Telephus of Euripides, University of London, Bull. Inst. Class. Stud. Suppl. 5.

Henderson, J. (1972), «The lekythos and Frogs 1200-1248», HSPh 76: 133-144. 


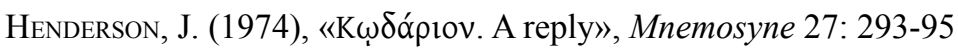

Hoppe, W. E. (1906), The Language of Parody. A Study in the diction of Aristophanes, Baltimore. HouseHolder, F. W. (1944), «ПAP $\Omega$ I $\Delta \mathrm{IA} », C P h .1-9$.

Hunziger, CH. (2000), «Aristophane, lecteur d'Euripide», en Leclant, J., Jouanna, J. Eds. (2000: 99-110).

JAmEs, E. (1969), «New comedy. Aristophanes and Euripides», Pegasus 11: 27-31.

Joun, F. Ed. (1983), Visages du destin dans les mythologies. Melanges Jacqueline Duchemin. Actes du Colloque de Chantilly $1^{\text {er }}-2$ mars 1980, Paris.

KopfF, E. C. (1977), «Nubes 1493 ff. Was Socrates murdered?», GRBS 18: 113-122.

KomornickA, A. M. (1967), «Quelques remarques sur la parodie dans les comédies d'Aristophane», QUCC 3: 51-74.

Kraus, W. (1975), «Aristophanes - Spiegel einer Zeitende», en Newiger, H.-J. Ed. (1975: 435-458).

Krieg, W. (1936), «Der trochaische Tetrameter bei Euripides», Philologus 91: 42-51.

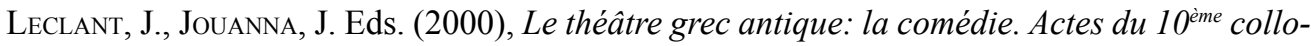
que de la Villa Kérylos à Beaulieu-sur-Mer, les $1^{\text {er }} \& 2$ octobre 1999. Paris

Lelièvre, F. J. (1954), «The Basis of ancient Parody», G\&R, Sec. Series 1: 66-81.

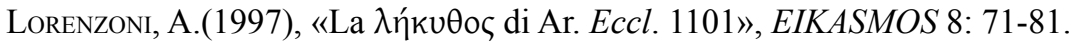

Magnini, E. (1997), «Alcune allusioni parodiche a passi di tragedie euripidee nelle Rane di Aristofane», Aevum (ant) 10: 127-138.

Mastromarco, G.(1994), «Public et mémoire theâtrale dans l'Athènes d'Aristophane», ConHell. 60: 8-12.

Mastromarco, G. (1997), «Pubblico e memoria teatrale nell’ Atene di Aristofane», en Thiercy, P., Menu, M. Eds. (1997: 529-48).

Mastromarco, G. (2006), «La paratrogodia, il libro, la memoria», en Medda, E., Mirto, M. ${ }^{a}$, PAtToni, M. ${ }^{\text {a }}$ P. Eds. (2006: 137-191).

Mastromarco, G. (2008), «La parodia dell'Andromeda euripidea nelle Tesmoforiazuse di Aristofane», $C F C(G)$ 18: 177-188.

Mazzacchera, E. (1999), «Agatone e la $\mu$ í Lexis 17: 205-224.

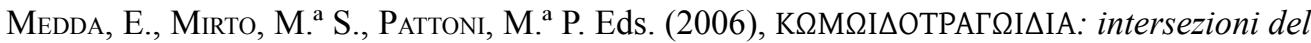
tragico e del comico nel teatro del $V$ secolo a. C. Atti delle giornate di studio, Pisa, Scuola Normale Superiore 24-25 giugno 2005, Pisa.

Micalella, D. (2005), «Euripide e Agatone nelle "Tesmoforiazuse” di Aristofane: due poetiche in confronto», SIFC 4. ${ }^{\text {a }}$ ser. 3: 188-194.

Mitdoerffer, W. (1954), «Das Mnesilochoslied in Aristophanes' Thesmophoriazusae», Philologus 98: 59-93.

Moorton, R. F. (1987), «Euripides’ Andromeda in Aristophanes’ Frogs», AJPh 97: 434-36.

Moorton, R. F. (1988), «Aristophanes on Alcibiades», GRBS 28: 345-59.

Murphy, C. T. (1938), «Aristophanes and the Art of Rhetoric», Harv. Stud. Class. Phil. 49: 63-113.

Murray, A. (1891), On Parody and Paratragoedia in Aristophanes, Berlin.

Newiger, H.-J. Hrsg. (1975), Aristophanes und die Alte Komödie, Darmstadt.

NiEDdu, G. F (2003), «Un poeta al lavoro: qualche riflessione sulla parodia dell' Elena nelle Tesmoforiazuse», en CASANova, A., Desideri, P. Eds. (2003:55-90). 
Nieddu, G. F. (2004), «A Poet at Work: the Parody of Helen in the Thesmophoriazusae», GRBS 44: 331-360.

Pascal, C. (1911), Dioniso. Saggio sulla religione e la parodia religiosa in Aristofane, Catania. Passow, W. (1897), De Aristophane defendendo contra invasionem Euripideam. I: de terminis parodiae. Progr. Hirschberg.

Pellegrino, M. (2008), «Il mito di Medea nella rappresentazione parodica dei commediografi greci», $C F C(G)$ 18: 201-216.

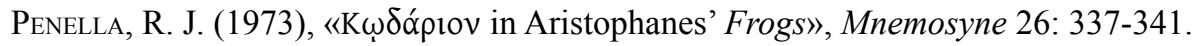

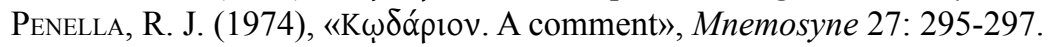

Perusino, F. a , Colantonio, M. ${ }^{\text {a }}$ (2004), «Echi dell' Auge di Euripide nella Lisistrata di Aristofane», QUCC N.S. 76: 123-126

Prato, C. (1955), Euripide nella critica di Aristofane, Galatina (Lecce).

Pretagostini, R. (1976), «Dizione e canto nei dimetri anapestici di Aristofane», SCO 25: 183-212.

Prete, S. Ed. (1986), Studi per Riccardo Ribuoli. Scritti di filologia, musicologia, storia, Roma.

Pucci, P. (1961), «Aristofane ed Euripide, Ricerche metriche e stilistiche, MAL, ser. VIII, vol 10, 358: 277-423.

RaU, P. (1967), Paratragodia. Untersuchung einer komischen Form des Aristophanes, München.

RAU, P. (1975), «Das Tragödienspiel in den 'Thesmophoriazusen», en Newiger, H.-J. (1975: 339-54).

RibBeck, W. R. (1861), De usu parodiae apud comicos Athenienses, Berl. Schulprogr.

RiвBEck, W. R. (1863), «Die Parodien bei den attischen Komikern», Zeitschr.f. Gymnasialw. 17.

RibBeck, W. R. (1864), Die Acharner des Aristophanes. Griechisch und Deutsch mit kritischen und erklärenden Anmerkungen und einem Anhang über die dramatischen Parodien bei den Attischen Komikern, Leipzig.

Robertson, G. W. (1974), "Aristophanes Ranae 862. A note on the anatomy of Euripidean tragedy», HSPh 78: 177-188.

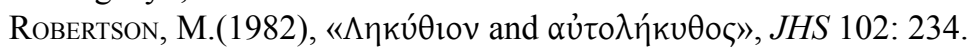

Roos, E. (1951), Die tragische Orchestik im Zerrbild der altattischen Komödie, Lund.

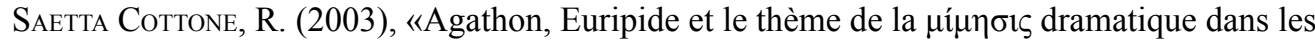
Thesmophories d'Aristophane », REG 116: 445-469.

Saetta Cottone, R. (2005), «Euripide, il nemico delle donne: studio sul tema comico delle Tesmoforiazuse di Aristofane», Lexis 23: 131-156.

Schlesinger, A. C. (1937), «Identification of Parodies in Aristophanes», AJPh 58: 294-305.

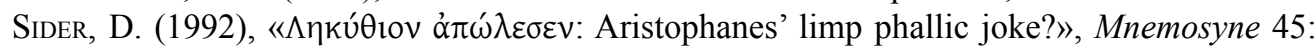
359-364

SNell, B.(1979), «Lekythion», Hermes 97: 129-133.

Sommerstein, A. H. (1974), «Aristophanes’ Frogs 1463-5», CQ 24: 24-27.

Sonnino, M. (1999), «Le strategie militari di Pericle e le Rane di Aristofane: (Aristoph. Ran. 1019-1025; 1435-1466)», SemRom 2: 65-97.

Steiger, H. (1934), «Die Groteske und die Burleske bei Aristophanes», Philologus 89, 161$184,275-285,416-432$.

Tammaro, V. (2006), «Poeti tragici come personaggi comici in Aristofane», en MedDA, E., Mirto, M. ${ }^{\text {a }}$ S., Pattoni, M. ${ }^{\text {a }}$ Eds.(2006: 249-261).

TARTAglini, C. (1986), «La pesatura nelle Rane di Aristofane», en Prete, S. Ed.(1986: 135-140).

TÄUBer, H. (1849), De usu parodiae apud Aristophanem, Berlin. 
Thiercy, P. (2010), «Le syllogisme aristophanien», en Cortés Gabaudan, F., MÉndez Dosuna, J. V. Eds. (2010: 669-676).

Thiercy, P., Menu, M. Eds. (1997), Aristophane: la langue, la scène, la cité. Actes du colloque de Toulouse 1994, BARI.

Van de Sande Bakhuyzen, W. H. (1887), De parodia in comoediis Aristophanis. Locos ubi Aristophanes verbis Epicorum, Lyricorum, Tragicorum utitur collegit et illustravit, Traiecti ad Rhenum.

Van Leeuwen, J. (1876), De Aristophane Euripidis censore, Amsterdam.

Vickers, M. (1989), «Alcibiades on stage: Thesmophoriazusae and Helen», Historia 38: 41-65.

VICKERS, M. (1989), «Alcibiades on stage: Aristophanes' Birds», Historia 38: 267-299.

Voelke, P. (2004), «Euripide, héros et poète comique: à propos des Acharniens et des Thesmophories d'Aristophane», EL 4: 117-138.

Von Wilamowitz-Moellendorff, U. (1975³), «Zu Aristophanes’ Fröschen», en Newiger, H.-J. (1975: 357-363).

Whitehorne, J. (2002), «Aristophanes' Representation of 'Intellectuals'», Hermes 130: 28-37.

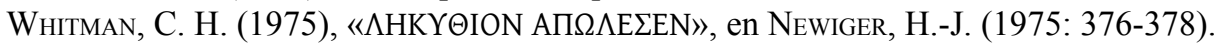

Zimmermann, B. (1987), «Ioniker in den Komödien des Aristophanes. Prolegomena zu einer interpretativen Metrik,», Prometheus 13: 124-132.

ZINK, C. (1983), Adnotationes ad Demosthenis orationem in Cononem, Erlangen. 